\title{
Panduan Penilaian Dasar Kesejahteraan Manusia
}

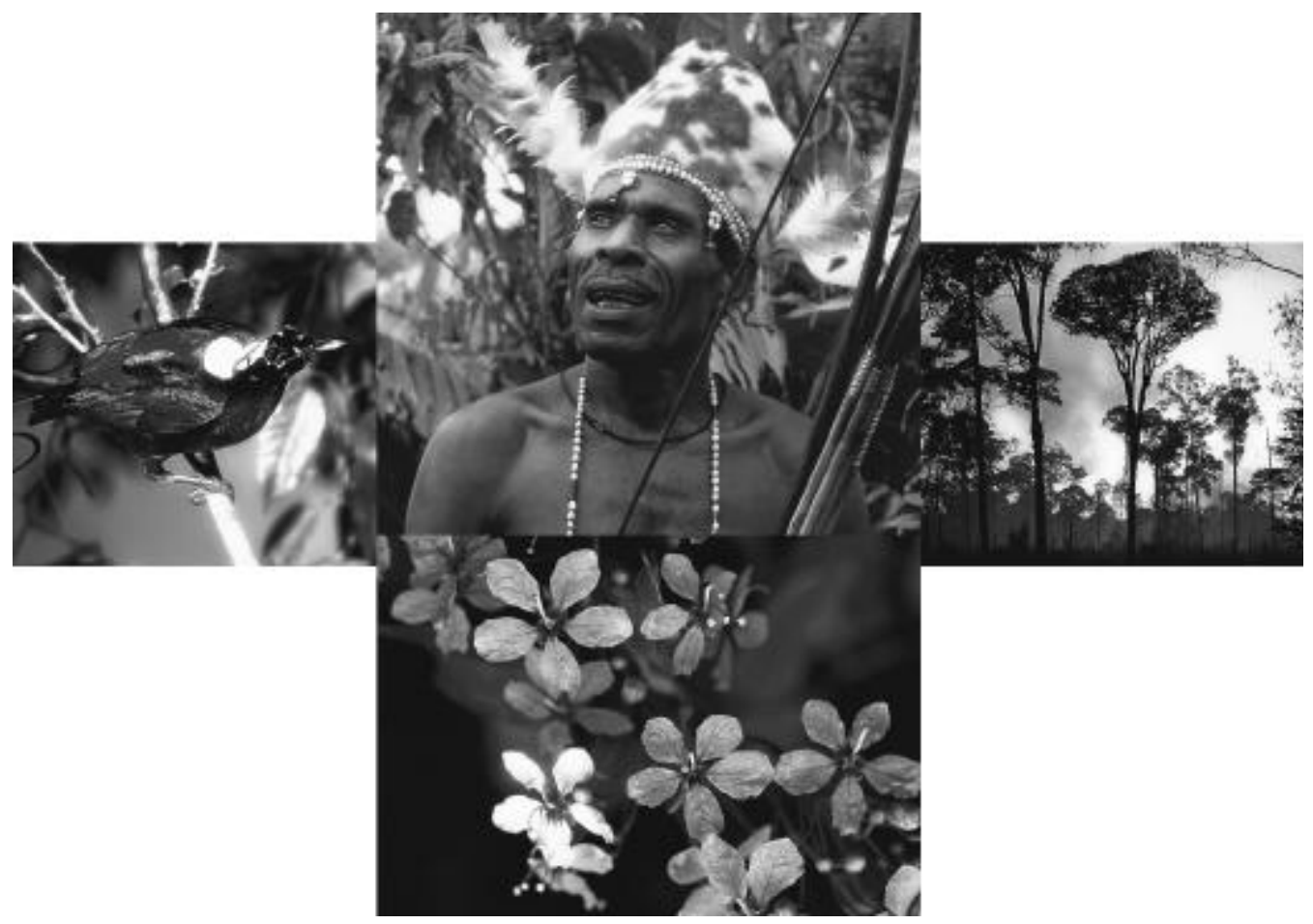




\section{Panduan Penilaian Dasar Kesejahteraan Manusia}

\section{Oleh Tim CIFOR untuk Pengujian Metode}

Carol J. Pierce Colfer, Mary Ann Brocklesby, Chimère Diaw, Priscilia Etuge, Mario Günter, Emily Harwell, Cynthia McDougall, Noemi Miyasaka Porro, Roberto Porro, Ravi Prabhu, Agus Salim, Mustofa Agung Sardjono, Bertin Tchikangwa, Anne Marie Tiani, Reed Wadley, Joe Woelfel dan Eva Wollenberg

Alih bahasa

Ani Kartikasari

\section{PERANGKAT KRITERIA DAN INDIKATOR}


(C) 1999 oleh Center for International Forestry Research

Dicetak oleh SMKGrafikaMardiYuana, Bogor

Fotografi

BurungCenderawasih oleh Alain Compost

Kebakaran hutan oleh Alain Compost

Orang Irianmemegang panah oleh Alain Compost

Bunga kuning olehAndy Gillison

Para penulis ingin menyatakan penghargaan kepada Herlina Hartanto, Herry Purnomo, Daju Pradnja Resosudarmo, Rahayu Koesnadi, Agus Salim, Abdurrahman Syebubakar, Meilinda Wan dan Yurdi Yasmi yang melakukan pengecekan kualitas terjemahan seri perangkat ini, dan juga kepada Meiske D. Tapilatu dan Dwiati Novita Rini yang melakukan pengecekan selama proses persiapan pencetakan.

ISBN: 979-8764-37-4

Diterbitkan oleh

Center for International Forestry Research (CIFOR)

Alamat: POBox6596JKPWB,Jakarta 10065, Indonesia

Telepon:+62-251-622622 Fax:+62-251-622 100

E-mail:cifor@cgiar.org

WWW: http://www.cgiar.org/cifor

Dengan dukungan dana dari

The European Commission

Anggaran B7-6021 yang berkaitan dengan 'Hutan Tropis'

Brusel, Belgia

Deutsche Gesellschaft für Technische Zusammenarbeit (GTZ) GmbH

Eschborn, Jerman

United States Agency for International Development (USAID)

Washington D.C., Amerika Serikat

Pencetakan edisi bahasa Indonesia ini sebagian besar didanai oleh kantor Ford Foundation di Indonesia. 


\section{Seri Perangkat K\&I}

\begin{tabular}{|c|c|}
\hline rangkat K\&I No. 1 & $\begin{array}{l}\text { Panduan untuk Pengembangan, Pengujian dan Pemilihan } \\
\text { Kriteria dan Indikator untuk Pengelolaan Hutan Lestari } \\
\text { Prabhu, R., Colfer, C.J.P. dan Dudley, R.G. }\end{array}$ \\
\hline rangkat K\&I No. 2 & $\begin{array}{l}\text { Acuan Generik Kriteria dan Indikator CIFOR } \\
\text { Tim K\&I CIFOR }\end{array}$ \\
\hline rangkat K\&I No. 3 & $\begin{array}{l}\text { Perangkat Modifikasi dan Adaptasi Kriteria dan Indikator } \\
\text { (CD-ROM) } \\
\text { Prabhu, R., Haggith, M., Purnomo, H., Rizal, A., Sukadri, } \\
\text { D., Taylor, J. dan Yasmi, Y. }\end{array}$ \\
\hline erangkat K\&I No. 4 & $\begin{array}{l}\text { Sistem Basis Data Kriteria dan Indikator CIFOR } \\
\text { McDougall, C., Isbadi, I.R., Santoso, L., Corless, M. dan } \\
\text { Pumomo, H. (ed.) }\end{array}$ \\
\hline tt K\&I No. 5 & $\begin{array}{l}\text { Panduan Penilaian Dasar Kesejahteraan Manusia } \\
\text { Colfer, C.J.P., Brocklesby, M.A., Diaw, C., Etuge, P., Günter, } \\
\text { M., Harwell, E., McDougall, C., Porro, N.M., Porro, R., } \\
\text { Prabhu, R., Salim, A., Sardjono, M.A., Tchikangwa, B., Tiani, } \\
\text { A.M., Wadley, R.L., Woelfel, J. dan Wollenberg, E. }\end{array}$ \\
\hline K\&I No. 6 & $\begin{array}{l}\text { Panduan Pendamping Penilaian Dasar Kesejahteraan } \\
\text { Manusia } \\
\text { Colfer, C.J.P., Brocklesby, M.A., Diaw, C., Etuge, P., Günter, } \\
\text { M., Harwell, E., McDougall, C., Porro, N.M., Porro, R., } \\
\text { Prabhu, R., Salim, A., Sardjono, M.A., Tchikangwa, B., Tiani, } \\
\text { A.M., Wadley, R.L., Woelfel, J. dan Wollenberg, E. }\end{array}$ \\
\hline Perangkat K\&I No. 7 & $\begin{array}{l}\text { Panduan Cara Pemberian Skor dan Analisis untuk Menilai } \\
\text { Kesejahteraan Manusia } \\
\text { Salim, A. dan Colfer, C.J.P., dengan McDougall, C. } \\
\end{array}$ \\
\hline Perangkat K\&I No. 8 & $\begin{array}{l}\text { Siapa yang Perlu Dipertimbangkan? Menilai Kesejahteraan } \\
\text { Manusia dalam Pengelolaan Hutan Lestari } \\
\text { Colfer, C.J.P, Prabhu, R., Günter, M., McDougall, C., Porro, } \\
\text { N.M. dan Porro, R. }\end{array}$ \\
\hline Perangkat K\&I No. 9 & $\begin{array}{l}\text { Panduan untuk Menerapkan Analisis Multikriteria dalam } \\
\text { Menilai Kriteria dan Indikator } \\
\text { Mendoza, G.A., dan Macoun, P. dengan Prabhu, R., Sukadri, } \\
\text { D., Purnomo, dan Hartanto, H. }\end{array}$ \\
\hline
\end{tabular}

Perangkat K\&I No. 10 Metodologi untuk Menilai Indikator Ekologis dalam Pengelolaan Hutan Lestari (Dalam Persiapan) 


\section{DAFTAR ISI}

Panduan Penilaian Kesejahteraan Manusia di Kawasan

Pembalakan Hutan ......................................................................... v

Panduan Penilaian Dasar Kesejahteraan Manusia .................................. 1

Taruhan Terbaik Kami ......................................................................

A. IDENTIFIKASI STAKEHOLDER …............................................ 9

1. Siapa saja yang berkepentingan? ............................................ 10

2. Analisis Kelompok Sasaran ................................................ 16

B. PENILAIAN KEAMANAN AKSES ANTARGENERASI TERHADAP SUMBER DAYA (40\%) …………....................... 23

1. Matriks sejarah-ekologi ............................................................. 26

2. Pemetaan Partisipatif ............................................................ 31

3. Akses suatu generasi terhadap sumber daya: Metode Distribusi Kerikil ...................................................... 35

C. PENILAIAN HAK DAN KEMAMPUAN UNTUK MENGELOLA HUTAN SECARA BERSAMA

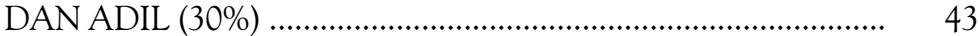

1. Hak/kemampuan untuk mengelola: distribusi kerikil ........... 47

D. PENILAIAN ISU-ISU LAINNYA (30\%) .................................... 57

E. PROSEDUR PEMBERIAN SKOR ………..................................... 63

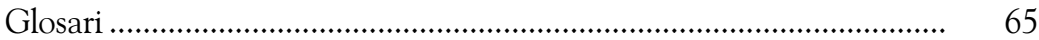

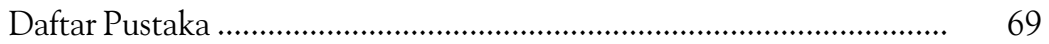




\section{PANDUAN PENILAIAN KESEJAHTERAAN MANUSIA DI KAWASAN PEMBALAKAN HUTAN}

Panduan ini dirancang untuk digunakan oleh individu dan organisasi yang ingin menilai kelestarian kegiatan penebangan hutan untuk diambil kayunya. Pengguna potensial panduan-panduan ini mencakup lembaga-lembaga sertifikasi, pengusaha yang bergerak di bidang perkayuan, badan-badan donor, masyarakat lokal, pemerintah, peneliti, dll. Panduan-panduan ini tidak hanya tepat untuk melakukan satu kali penilaian, tetapi dapat juga digunakan sebagai bagian dari program pemantauan yang dapat mendukung peningkatan kondisi hutan dan juga perbaikan kondisi masyarakat. Kegiatankegiatan CIFOR sebelumnya dan pihak lainnya telah menyimpulkan bahwa kesejahteraan masyarakat yang hidup di kawasan di mana pembalakan komersial sedang berlangsung (dan juga pemeliharaan/perbaikan fungsi ekologi) sangat menentukan kelestarian pengelolaan hutan, baik untuk alasan pragmatis atau etis.

Tantangan untuk menilai kesejahteraan manusia secara cepat, mudah dan dapat diandalkan memacu CIFOR untuk memulai suatu studi perbandingan metode-metode ilmu sosial yang sesuai untuk digunakan dalam penilaian seperti ini (lihat Colfer 1997). Panduan-panduan ini telah dikembangkan berdasarkan hasil pengujian metode-metode secara sistematis di Kamerun, Indonesia, dan Brasil, serta kegiatan tambahan di Trinidad, Gabon dan Amerika Serikat. Dalam mengevaluasi pengelolaan hutan lestari, diasumsikan bahwa para penilai akan mendatangi kamp kerja perusahaan kayu dan desa-desa, mengajukan pertanyaan yang tepat tentang masyarakat di kawasan tersebut, dan memeriksa data yang tersedia di perusahaan dan kantor-kantor pemerintah lokal, serta menggunakan metode-metode yang disarankan di sini. 
Panduan penilaian ini didasarkan pada serangkaian kriteria dan indikator (atau K\&I), yang dikembangkan oleh tim CIFOR di seluruh dunia. K\&I global ini dimaksudkan untuk dipakai sebagai pola dasar untuk melakukan penilaian kelestarian suatu hutan tertentu (termasuk kesejahteraan penduduk yang hidup di dalam dan sekitarnya). Idealnya, set K\&I global ini akan disesuaikan dengan kondisi lokal (lihat CIMAT dan komponen lain Kumpulan Peralatan K\&I CIFOR untuk perangkat adaptasi).

Kami memberikan fokus pada isu-isu sosial kritis yang nyata, dan berasumsi bahwa isu-isu ekologi dan kehutanan konvensional juga akan dibahas dalam penilaian kelestarian suatu hutan tertentu. Kami juga merekomendasikan untuk memasukkan data referensi spasial (ruang), untuk digunakan dalam aplikasi GIS dan untuk memudahkan hubungan dengan data sensus atau data rumah tangga. Dalam rangka memudahkan (kemampuan) para pengguna untuk dapat mengambil keputusan tentang apakah suatu hutan dikelola secara lestari, kami menyarankan serangkaian langkah dan sistem pemberian skor yang dapat dijadikan pengukur isu-isu sosial secara diferensial, berdasarkan pada pengalaman kami sebelumnya.

Penilaian terbaik tentang kesejahteraan manusia biasanya dilakukan oleh ilmuwan sosial yang terlatih. Namun, karena tidak semua kelompok yang berkepentingan untuk penilaian seperti ini mempunyai akses untuk mendapatkan tenaga ahli seperti ini, maka kami telah menerbitkan dua panduan yang terpisah. Pertama, Panduan Penilaian Dasar (PPD), menyediakan sebuah pendekatan 'buku resep' untuk melakukan penilaian. Panduan ini tidak mencerminkan idealisme kami. Namun, kami percaya panduan ini dapat memberikan petunjuk dalam kasus-kasus di mana penilai bukan ilmuwan sosial yang kompeten. Setiap penilai akan membutuhkan ketrampilan dalam hal-hal berikut: 
- Kemampuan dan motivasi untuk berkomunikasi dengan sikap terbuka dan menyenangkan dengan stakeholder yang sangat beragam, termasuk terutama masyarakat lokal dan para karyawan;

- Akses untuk mendapatkan penerjemah sesuai kebutuhan;

- Kesabaran untuk mendorong dan memperoleh informasi dari kelompok yang kurang terlibat, seperti wanita, orang kecil, golongan masyarakat berkasta rendah;

- Kemampuan untuk menimbang informasi dengan sikap yang tidak bias, terutama menghindari peran pembela untuk satu kelompok stakeholder tertentu;

- Kesadaran akan perbedaan budaya dan keingintahuan tentang sistem pengelolaan lokal; dan

- Waktu yang cukup di lapangan untuk melakukan penilaian (idealnya paling sedikit sebulan).

Ada lima langkah utama dalam PPD:

1. Identifikasi stakeholder yang relevan;

2. Penilaian keamanan akses antargenerasi terhadap sumber daya;

3. Penilaian hak dan tanggung jawab untuk mengelola hutan secara bersama-sama;

4. Penilaian terhadap kesehatan hutan (forest health), para pengguna hutan dan budayanya; dan

5. Metode ringkas pemberian skor.

Pembahasan berikut tentang masing-masing metode menyediakan saransaran pengambilan sampel dan bahan-bahan yang dibutuhkan. Upaya yang terus-menerus perlu dilakukan untuk mencerminkan keragaman stakeholder di kawasan itu, dengan kepentingan, kondisi dan masalah masing-masing. 
Kelompok stakeholder ini mencakup wanita, kelompok etnis yang tersisih, kelompok umur yang kurang terwakili, kaum miskin, dan kelompok lain yang biasanya terabaikan. Penting juga untuk dipertimbangkan isu-isu mengenai perwakilan, dan pastikan bahwa Anda akan mendapatkan pandangan yang seluas mungkin dari keragaman para penggunanya. Manfaat penggunaan bahasa lokal sebanyak mungkin sangat penting. Penilaian akan lebih mudah dan lebih cepat jika Anda dapat menggunakan komputer laptop. Setiap metode memerlukan bahan-bahan tertentu, tetapi umumnya tidak mahal (kertas, pena, kerikil atau kacang, lembaran kertas berukuran besar, pena berwarna, peta, dll.).

Bacalah panduan secara keseluruhan sebelum memulai penilaian, karena langkah-langkah awal akan sangat membantu langkah-langkah selanjutnya, jika Anda peka dan sudah siap.

Panduan Pendamping Penilaian Dasar (PPPD) menyediakan sejumlah metode tambahan yang kami temukan sangat berguna. Walaupun metode-metode ini dipandang sangat berharga oleh ilmuwan sosial dalam uji lapang, metode ini telah dipisahkan dari 'buku resep' karena bertumpang tindih dengan metode lain dalam PPD atau karena kesulitannya bagi ilmuwan nonsosial. Dapat dimengerti bahwa ilmuwan sosial yang berkualifikasi mungkin akan lebih memilih metode yang dipertimbangkan cocok untuk situasi tertentu; namun demikian, keahlian mereka mungkin akan sia-sia jika mereka diminta mengikuti prosedur yang diperintahkan seperti yang diusulkan dalam PPD. Pendekatan-pendekatan yang disarankan dalam PPPD memberikan cukup banyak kesempatan untuk menggunakan pertimbangan profesional. Tujuan kami adalah memberikan kesempatan kepada ilmuwan sosial terlatih untuk memeriksa semua metode yang dijelaskan dan memilih yang paling sesuai untuk kawasan yang sedang dinilai. 
Perangkat K\&I ketiga yang sangat erat hubungannya adalah Panduan Cara Pemberian Skor dan Analisis untuk Menilai Kesejahteraan Manusia. Perangkat ini menyajikan cara-cara pemberian skor dan membantu dalam membuat pertimbangan-pertimbangan kualitatif secara sistematis, sehingga semua K\&I dapat dinilai dan dievaluasi. Bagian yang membahas analisis hanya memerlukan sedikit ketrampilan komputer, dan secara hati-hati memandu pembaca melakukan tahap-tahap yang diperlukan untuk menganalisis data kuantitatif (misalnya, dari metode distribusi kerikil atau penyortiran kartu), mulai dari memasukkan data awal melalui prosedur statistik yang mungkin diinginkan oleh para pengguna. Penjelasan untuk memasukkan data awal ini menggunakan lembar isian Excel dan SPSS. 


\section{PANDUAN PENILAIAN DASAR KESEJAHTERAAN MANUSIA}

'Buku resep' ini ditujukan bagi mereka yang berharap untuk menilai kelestarian hutan yang dikelola secara komersial untuk diambil kayunya. Buku ini mengakui kemungkinan adanya penduduk yang tinggal di dalam dan di sekitar kawasan hutan yang kayunya diambil, sehingga untuk pengelolaannya secara lestari kesejahteraan penduduk perlu diperhatikan. 'Buku resep' ini ditulis dengan asumsi adanya prosedur untuk penilaian lainnya untuk pertimbangan ekologis dan pengelolaan hutan konvensional.

Karena ketidakpastian kami tentang kualifikasi para calon pengguna panduan ini, pengguna sasaran kami adalah orang yang bergelar sarjana di bidang ilmu alam dan yang sederajat. Kami berharap bahwa para penilai juga memiliki pengalaman di bidang ilmu sosial. Dalam kondisi seperti ini, kami berharap pengguna dapat leluasa menggunakan metode-metode alternatif dan metode tambahan yang tersedia dalam Panduan Pendamping Penilaian Dasar Kesejahteraan Manusia - PPPD (yang bagian-bagian relevannya dicantumkan dalam Panduan Penilaian Dasar Kesejahteraan Manusia-PPD).

PPD direncanakan untuk membantu Anda mengumpulkan informasi yang akan Anda perlukan untuk menilai prinsip, kriteria dan indikator yang terdaftar di bawah. Kami berharap Anda dapat selalu mengingat P, K \& I, sambil Anda memahami metode yang diuraikan di bawah. Dengan demikian Anda akan dibantu untuk membuat penilaian yang adil dan akurat tentang kesejahteraan manusia lokal/setempat. Langkah pertama yang Anda perlu lakukan adalah memasukkan prinsip, kriteria, dan indikator ke dalam sebuah lembar isian/spreadsheet, sebaiknya dalam sebuah komputer, yang kemudian dapat Anda acu dan tambahkan dalam proses penilaian keseluruhan (lihat 
contoh dalam Panduan Cara Pemberian Skor dan Analisis untuk Menilai Kesejahteraan Manusia).

\section{Ada lima langkah utama dalam melakukan PPD:}

1. Identifikasi stakeholder yang relevan;

2. Penilaian keamanan akses antargenerasi terhadap sumber daya;

3. Penilaian hak dan kemampuan untuk mengelola hutan secara bersama dan adil;

4. Penilaian terhadap kesehatan hutan (forest health), para pengguna hutan dan budayanya; dan

5. Metode pemberian skor.

Metode pemberian skor didasarkan pada skala 1-10, diukur berdasarkan kepentingan prinsip. Panduan Cara Pemberian Skor dan Analisis untuk Menilai Kesejahteraan Manusia tersedia dalam Perangkat K\&I CIFOR untuk membantu Anda membuat penilaian kualitatif ini.

Bacalah setiap langkah berikut sebelum memulai penilaian Anda.

Kita harus mengawali usaha ini dengan suatu peringatan. K\&I sosial (dan lebih umum lagi penilaian kesejahteraan manusia) tetap merupakan topik paling pelik dalam usaha mengidentifikasi K\&I yang berguna. Dalam mengembangkan K\&I ini kami telah mengambil pendekatan 'iteratif', dimulai dengan sebuah kerangka kerja konseptual (Colfer dkk. 1995), melakukan pengujian K\&I di berbagai lokasi (Prabhu dkk. 1996; Federal Ministry for Environment, Youth and Family 1996, Colfer dkk. 1996a, b; 1997a), secara berkesinambungan mengembangkannya (Prabhu dkk. 1998; 
Colfer dkk. 1997b). Kami menganggap bahwa K\&I yang telah didaftar masih tetap bersifat sementara, tetapi menyajikan hasil berbagai revisi terhadap versi-versi sebelumnya.

Kami mencatat beberapa kesimpulan penting yang telah kami capai berdasarkan uji lapang kami di seluruh dunia:

1. Variasi di antara berbagai lokasi, dalam hal K\&I sosial yang diusulkan, lebih besar daripada variasi antara K\&I untuk ekologi dan K\&I untuk kehutanan - mencerminkan variasi manusia dan juga kesulitan metodologi dalam membuat penilaian kesejahteraan manusia.

2. Kesepakatan pada tingkat prinsip dan kriteria lebih besar daripada di tingkat indikator atau pengukur, lagi-lagi mencerminkan banyak manifestasi kesejahteraan manusia dan kemungkinan bahwa indikator dan pengukur selalu akan memerlukan penyesuaian lokal.

3. Tiap metode yang telah kami uji memerlukan beberapa 'perbaikan atau penyesuaian' di lapang (misalnya: bahasa, identifikasi stakeholder, hasil hutan yang relevan) dan kami percaya penyesuaian ini tidak dapat dihindari.

Definisi kami tentang kelestarian mencakup pemeliharaan atau perbaikan terhadap kesejahteraan manusia dan terhadap fungsi ekologis suatu hutan. Pemberian skor yang disediakan dalam panduan ini dimaksudkan untuk menyediakan sepertiga dari skor total dalam penilaian kegiatan pengambilan kayu secara lestari. Skor untuk kesejahteraan manusia ini dimaksudkan untuk diintegrasikan dengan skor dari berbagai fungsi ekologis dan dari kegiatan kehutanan konvensional (lihat 'Kotak Peralatan' CIFOR untuk panduanpanduan lain yang relevan). 
Kami telah memilih sebagian besar metode yang menggunakan ukuran sampel yang tidak bervariasi menurut ukuran populasinya. Pilihan ini kami ambil dengan asumsi bahwa jangka waktu yang pendek untuk kerja lapang dan perhatian terhadap keterwakilan keragaman manusia setempat lebih penting dibandingkan pertimbangan-pertimbangan statistik. Namun demikian, jika waktu dan sumber daya mengijinkan, peningkatan ukuran sampel untuk populasi yang lebih besar (pengambilan sampel secara proporsional) akan lebih disukai.

Panduan ideal (masa depan) akan menyediakan metode yang spesifik untuk menilai setiap indikator yang dipandang penting, yang lebih lanjut dapat dijumlahkan untuk menyediakan suatu skor untuk masing-masing kriteria. Kami masih belum mencapai tingkat ini. Untuk sementara, kami menyajikan metode-metode yang menyediakan data yang dapat memberi sumbangan terhadap pengertian Anda tentang isu-isu yang diindentifikasi dalam K\&I terutama kriterianya, karena kriteria ini telah terbukti lebih luas tingkat aplikasinya daripada indikator khusus. Kami minta penilai untuk membuat estimasi berdasarkan informasi yang dimiliki, sesuai dengan Panduan Pemberian Skor dan Analisis untuk Menilai Kesejahteraan Manusia, untuk masing-masing indikator, dan memadukannya untuk skor akhir penilaian kelestarian. Pertimbangan-pertimbangan dalam mengambil keputusan masih tetap penting dalam penggunaan panduan ini dan juga dalam penilaian kesejahteraan manusia secara umum. 


\section{TARUHAN TERBAIK KAMI}

\section{P. 1 PENGELOLAAN HUTAN MENJAGA ATAU MENINGKATKAN AKSES ANTARGENERASI TERHADAP SUMBER DAYA DAN BERBAGAI MANFAAT EKONOMI SECARA ADIL}

\section{K. 1.1 Pihak pengelola lokal dapat secara efektif mengendalikan pemeliharaan dan akses terhadap sumber daya ${ }^{1}$}

I. 1.1.1 Kepemilikan dan hak untuk menggunakan sumber daya (dalam satu generasi atau antargenerasi) jelas dan mengakui klaim yang sudah ada

I. 1.1.2 Berbagai aturan dan norma dalam penggunaan sumber daya dipantau dan ditegakkan pelaksanaannya

I. 1.1.3 Cara-cara untuk mengatasi konflik berfungsi baik tanpa menggunakan kekerasan

I. 1.1.4 Akses terhadap sumber daya dianggap adil oleh masyarakat lokal

I. 1.1.5 Masyarakat lokal merasakan keamanan aksesnya terhadap sumber daya

K. 1.2 Para pengelola hutan memperoleh manfaat ekonomi yang cukup dari hasilhasil hutan yang diambilnya

I. 1.2.1 Mekanisme distribusi manfaat dianggap adil oleh masyarakat lokal

I. 1.2.2 Adanya kesempatan bagi masyarakat lokal dan masyarakat yang menggantungkan hidupnya pada hutan untuk memperoleh pekerjaan dari perusahaan-perusahaan kehutanan

I. 1.2.3 Upah dan tunjangan lainnya sesuai dengan standar nasional dan/atau ILO

I. 1.2.4 Ganti rugi terhadap kerusakan diberikan secara adil

Kriteria ini sangat erat kaitannya dengan kriteria yang ditinjau dari segi ekologi dan 'pengelolaan hutan' formal. 
I. 1.2.5 Berbagai hasil hutan digunakan secara optimal dan adil

K. 1.3 Masyarakat mengaitkan masa depan mereka dan anak-anak mereka dengan pengelolaan sumber daya hutan

I. 1.3.1 Masyarakat menanamkan modal di lingkungannya (misalnya, waktu, tenaga, uang)

I. 1.3.2 Tingkat migrasi keluar rendah ${ }^{2}$

I. 1.3.3 Masyarakat menyadari pentingnya keseimbangan antara jumlah penduduk dengan pemanfaatan sumber daya alam

I. 1.3.4 Anak-anak mendapatkan pendidikan (formal dan informal) tentang pengelolaan sumber daya alam

I. 1.3.5 Perusakan sumber daya alam oleh masyarakat lokal jarang terjadi

I. 1.3.6 Masyarakat memelihara hubungan batin dengan lahan hutan

P. 2 STAKEHOLDER YANG RELEVAN MEMILIKI HAK DAN KEMAMPUAN YANG DIAKUI UNTUK MENGELOLA HUTAN SECARA BERSAMA DAN ADIL

K. 2.1 Adanya berbagai mekanisme yang efektif untuk melakukan komunikasi dua arah antara para stakeholder dalam kaitannya dengan pengelolaan hutan

I. 2.1.1 > 50\% dari pegawai Departemen Kehutanan dan Perkebunan dan karyawan HPH dapat berbicara dalam satu atau beberapa bahasa lokal, atau > 50\% wanita lokal dapat menggunakan bahasa yang digunakan oleh HPH dalam berinteraksi

2 Indikator 1.3.2 dan 3.1.2 berpotensi untuk kontradiktif. Tingkat migrasi keluar yang rendah (I.1.3.2) mengindikasikan hubungan antara masa depan penduduk dan anak-anak mereka dengan pemeliharaan hutan; sementara itu kesadaran tentang perlunya keseimbangan antara jumlah penduduk dengan penggunaan sumber daya alam (I.3.1.2) mungkin membuat mereka memilih untuk bermigrasi keluar. Biasanya kontradiksi ini kemungkinan besar terjadi ketika kondisi-kondisi memburuk. 
I. 2.1.2 Para stakeholder lokal bertemu dengan frekuensi yang cukup, keragaman lokal cukup terwakili, dan dengan kualitas interaksi yang cukup

I. 2.1.3 Kontribusi masing-masing stakeholder saling dihormati dan dihargai secara wajar

K. 2.2 Para stakeholder lokal memiliki pengetahuan yang lengkap tentang penggunaan sumber daya hutan (termasuk pengetahuan tentang kelompok-kelompok pengguna hutan dan peranan jender), dan juga pengetahuan tentang rencana pengelolaan hutan sebelum rencana tersebut dilaksanakan

I. 2.2.1 Adanya rencana/peta-peta yang menunjukkan pengintegrasian berbagai penggunaan hutan oleh berbagai stakeholder yang berbeda

I. 2.2.2 Rencana yang diperbarui, studi-studi dasar dan peta dapat diperoleh dengan mudah, yang menunjukkan rincian kawasan seperti penebangan hutan dan pembangunan jalan, disertai kerangka waktunya

I. 2.2.3 Studi-studi dasar tentang sistem masyarakat lokal juga tersedia dan diacu

I. 2.2.4 Pegawai pengelola hutan mengakui adanya berbagai kepentingan dan hak stakeholder lainnya

I. 2.2.5 Pengelolaan HHNK mencerminkan kepentingan dan hak-hak stakeholder lokal

K. 2.3 Ada kesepakatan tentang hak-hak dan berbagai kewajiban stakeholder yang relevan

I. 2.3.1 Tingkat konflik yang ada dapat diterima oleh para stakeholder

\section{P. 3 KESEHATAN HUTAN, PARA PENGELOLA HUTAN DAN BUDAYANYA DAPAT DITERIMA OLEH SEMUA STAKEHOLDER}

K. 3.1 Ada keseimbangan yang cukup baik antara berbagai kegiatan manusia dan kondisi lingkungannya 
I. 3.1.1 Berbagai kondisi lingkungan yang dipengaruhi oleh kegiatan manusia tetap dalam keadaan stabil atau membaik

I. 3.1.2 Migrasi masuk dan/atau pertambahan penduduk secara alami selaras dengan pemeliharaan hutan

\section{K. 3.2 Ada pengakuan terhadap hubungan antara kesehatan masyarakat dengan} pengelolaan hutan

I. 3.2.1 Pihak pengelola hutan bekerjasama dengan petugas kesehatan masyarakat dalam mengatasi berbagai penyakit yang berkaitan dengan pengelolaan hutan

I. 3.2.2 Status gizi masyarakat lokal cukup baik (misalnya, tingkat pertumbuhan tinggi dan berat badan anak-anak sesuai dengan standar internasional, tingkat kematian bayi dan balita rendah) $)^{3}$

I. 3.2.3 Para pegawai yang bekerja di bidang kehutanan memperhatikan persyaratanpersyaratan dan keamanan kerja sesuai dengan standar ILO dan bertanggung jawab atas risiko kesehatan yang berkaitan dengan pekerjaan mereka

K. 3.3 Ada pengakuan terhadap pentingnya keterkaitan antara pemeliharaan hutan dengan kebudayaan

I. 3.3.1 Para pengelola hutan dapat menjelaskan keterkaitan antara budaya masyarakat dengan hutan lokal

I. 3.3.2 Rencana-rencana pengelolaan hutan mencerminkan perhatian terhadap isuisu yang terkait dengan kebudayaan

I. 3.3.3 Tidak ada tanda-tanda tentang adanya perpecahan budaya

3 Fakta bahwa indikator ini tidak selalu harus berhubungan langsung dengan kriterianya merupakan salah satu contoh kelemahan kriteria ketiga ini, yang disebabkan oleh kurangnya pengujian di lapangan yang dilakukan secara sistematis - dibandingkan dengan kedua kriteria lainnya. 


\section{Adentifikasi Stakeholder ${ }^{4}$}

Langkah pertama dalam setiap prosedur penilaian yang berhubungan dengan kesejahteraan manusia di dalam hutan yang dikelola untuk menghasilkan kayu adalah mengidentifikasi stakeholder yang relevan. Meminta suatu perusahaan kayu di Afrika untuk bertanggung jawab terhadap kesejahteraan konsumen hijau di AS memang tidak masuk akal; namun demikian ide bahwa perusahaan kayu ikut bertanggung jawab terhadap kesejahteraan manusia di kawasan terdekatnya diterima secara luas. Identifikasi yang benar terhadap para 'pengelolaan hutan' sangat penting untuk membuat penilaian yang garis besarnya akan diberikan satu persatu dalam panduan ini.

Di sini kami mengusulkan proses yang terdiri dari dua tahap untuk mengidentifikasi stakeholder yang relevan dalam pengelolaan hutan lestari. Tahap pertama 5 disebut 'Matriks siapa saja yang berkepentingan'. Tahap ini menyediakan cara sederhana untuk mengambil batas di antara stakeholder yang perlu mendapat perhatian khusus oleh perusahaan dan stakeholder yang tidak. Tahap kedua disebut 'Analisis Kelompok Sasaran' (Proyek Mt. Cameroon 1996). Analisis kelompok sasaran mengidentifikasi siapa saja kelompok masyarakat dalam kawasan yang dianggap penting dan bagaimana peran mereka.

4 Dalam Panduan Pendamping Penilaian Dasar Kesejahteraan Manusia, kami menyediakan dua metode tambahan untuk membantu membuat penilaian ini: pengujian Wollenberg (1997) dan analisis jaringan kerja neural CatPac oleh Woelfel.

5 Urutan ini dapat dibalikkan jika penilai merasa tidak dapat mengidentifikasi peran para stakeholder. Namun, secara umum kami menemukan bahwa identifikasi secara kasar yang diperlukan untuk Matriks siapa saja yang berkepentingan, cukup mudah untuk dikembangkan, dengan sedikit bantuan dari masyarakat setempat. 


\section{SIAPA SAJA YANG BERKEPENTINGAN? ${ }^{6}$}

\section{TUJUAN}

Mengidentifikasi satu kelompok kecil stakeholder yang berhubungan erat dengan hutan, yang perlu dilibatkan dalam penilaian dan pengelolaan hutan. Beberapa set informasi tentang para pengelola hutan ini akan dikumpulkan, untuk digunakan dalam menilai kesejahteraan masyarakat lokal.

\section{METODE}

Metode ini melibatkan pembuatan sebuah matriks. Identifikasi awal stakeholder yang penting ditulis melintang di bagian atas. Identifikasi ini dapat didasarkan pada pengetahuan sebelumnya, wawancara dengan kelompok berpengetahuan, pustaka yang ada. Melalui pembicaraan informal dengan pegawai negeri lokal dan anggota masyarakat, Anda dapat mengembangkan pengertian Anda tentang kemungkinan stakeholder. Pada kolom kiri didaftar tujuh dimensi: kedekatan dengan hutan, klaim-klaim yang sudah ada, ketergantungan, kemiskinan, pengetahuan lokal, integrasi budaya/hutan dan defisit kekuasaan - didefinisikan di bawah dalam kotak. ${ }^{7}$ Dimensi ini mencerminkan pentingnya hutan bagi masyarakat.

6 Metode ini diuraikan secara lebih terinci dalam Colfer dkk. (1999).

7 Penggabungan 'pengetahuan lokal' dan 'integrasi hutan/budaya' sudah banyak dibicarakan. Walaupun dalam panduan ini kami belum menerapkannya, mungkin penggabungan ini masuk akal bila diterapkan dalam beberapa konteks. 'Kemiskinan' telah dihapus dalam beberapa pengujian metode; dan 'etika konservasi' telah dipertimbangkan sebagai dimensi yang mungkin dapat dimasukkan. 


\section{PEMBERIANSKOR}

Setelah stakeholder dan kelompok pengguna didaftar melintang di bagian atas halaman, tetapkan skornya untuk setiap dimensi pada tingkat yang sesuai:

\begin{tabular}{|lll|}
\hline 1 & $=$ & tinggi \\
2 & $=$ & sedang \\
3 & $=$ & rendah \\
'var' & $=$ & bervariasi
\end{tabular}

Proses pemberian skor melibatkan pembuatan estimasi berdasarkan observasi awal Anda dan pandangan masyarakat yang Anda temui. Skor rata-rata untuk setiap kolom (kecuali skor 'bervariasi') dihitung melintang di bagian bawah setiap tabel. Dari pengalaman kami, nilai penentu dalam menentukan siapa saja yang berkepentingan, adalah nilai $<2$. Diskusikan estimasi ini dengan yang lain dan perbaiki agar sesuai.

Kemudahan metode-metode lainnya yang disajikan dalam panduan ini sebagian bergantung pada kecilnya jumlah kelompok yang berkepentingan (selanjutnya disebut 'pengelola hutan') - idealnya di antara tiga dan tujuh. Ujilah kategori kelompok pengguna/stakeholder Anda secara kritis untuk melihat apakah Anda dapat dengan aman menggabungkan beberapa di antaranya dan apakah Anda telah memperhitungkan keragaman masyarakat yang paling penting. Buat seleksi akhir pengelola hutan yang kesejahteraannya akan Anda nilai lebih lanjut. 


\section{SAMPEL FORMULIR}

\section{Contoh dari Pantai Gading}

\section{Stakeholder}

\begin{tabular}{|c|c|c|c|c|c|c|c|c|c|c|}
\hline Dimensi & 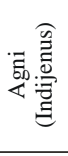 & 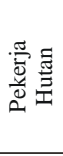 & 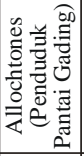 & 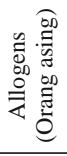 & 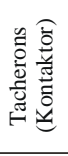 & 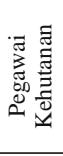 & 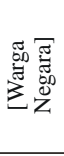 & 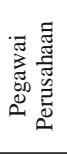 & 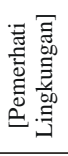 & 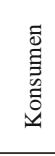 \\
\hline $\begin{array}{l}\text { Kedekatan } \\
\text { dengan hutan }\end{array}$ & 1 & 1 & 1 & 1 & 2 & 3 & 3 & 3 & 3 & 3 \\
\hline $\begin{array}{l}\text { Hak-hak yang } \\
\text { sudah ada }\end{array}$ & 1 & var & 2 & 3 & var & 2 & 2 & 3 & 3 & 3 \\
\hline Ketergantungan & 1 & 1 & 1 & 1 & 2 & 1 & 3 & 1 & 3 & 3 \\
\hline Kemiskinan & 1 & 1 & 1 & 1 & 2 & 3 & var & 3 & var. & var. \\
\hline $\begin{array}{l}\text { Pengetahuan } \\
\text { lokal }\end{array}$ & 1 & 2 & 2 & 2 & 2 & 3 & 3 & 3 & 3 & 3 \\
\hline $\begin{array}{l}\text { Integrasi } \\
\text { budaya/hutan }\end{array}$ & 1 & 2 & 2 & 2 & var & 3 & 2 & 3 & 2 & 3 \\
\hline Defisit Kekuasaan & 1 & 1 & 1 & 1 & 2 & 3 & var & 3 & 3 & var. \\
\hline NILAI & 1,14 & 1,33 & 1,43 & 1,57 & 2,00 & 2,57 & 2,60 & 3,17 & 2,83 & 3,00 \\
\hline
\end{tabular}

$1=$ tinggi, $2=$ sedang, $3=$ rendah 


\section{DEFINISI}

\section{Kedekatan dengan Hutan}

Kedekatan yang dimaksud di sini secara sederhana adalah kedekatan jarak dengan hutan. Kami mengakui potensi masyarakat yang tinggal di dekat hutan memiliki dampak cukup penting terhadap hutan. Masyarakat yang memiliki akses mudah ke hutan akan menguntungkan jika dilibatkan dalam pengelolaan hutan. Masyarakat di sekitar hutan yang merasa dirinya tidak diikutsertakan juga memiliki kemampuan, secara langsung atau tidak, untuk menyebabkan kerusakan hutan. Beberapa peneliti telah menyarankan untuk memasukkan kedekatan emosi, dan juga fisik, dalam dimensi ini, karena dalam beberapa kasus mereka yang peduli tentang hutan bertindak berdasarkan kedekatan emosi ini (kadang dari jauh).

\section{Hak-hak yang Sudah Ada}

Di banyak tempat, hutan yang terancam umumnya berada dalam keadaan konflik klaim tanah, bahkan sampai konflik paradigma tentang arti kepemilikan dan penggunaan lahan. Kadang masyarakat yang telah melakukan kegiatan dalam kawasan tertentu selama beberapa dekade, abad bahkan milenium, akhir-akhir ini hak tradisional mereka telah direbut atau sangat ditekan. Jika ada masyarakat seperti ini di dekat atau di dalam hutan, pengakuan hak-hak mereka sangat penting baik secara etis maupun pragmatis. Keadilan mengharuskan hak masyarakat terhadap hutan diakui dan dihormati. Dari pandangan praktis, pandangan akan ketidakadilan dapat mengarahkan pada berbagai tindakan buruk, dari ketidakacuhan terhadap kebijakaan hutan sampai pada peningkatan konflik, vandalisme dan kekerasan. 


\section{Ketergantungan}

Dalam banyak kawasan berhutan terdapat masyarakat yang hidupnya bergantung pada berbagai barang dan jasa dari hutan. Masyarakat mungkin berburu, menangkap ikan, mengumpulkan makanan, obat dan serat, atau melakukan agroforestri. Masyarakat seperti ini biasanya hanya memiliki sedikit alternatif yang realistis dari cara kehidupan mereka yang mereka jalani saat ini (mengenali bahwa hal ini tentu saja dapat berubah). Kebutuhan masyarakat yang penghidupannya bergantung pada hutan harus dipadukan ke dalam pengelolaan hutan lestari. Secara etis, akses masyarakat terhadap makanan merupakan pertimbangan penting. Secara praktis, masyarakat yang anaknya lapar tetapi karena mereka tidak diberi akses ke hutan mungkin tidak akan menghormati batas-batas hutan.

\section{Kemiskinan}

Konsep ini banyak sekali kelemahannya, karena pengertian tentang artinya berbeda di seluruh dunia. Dalam konteks ini, perhatian kami adalah untuk membedakan pengguna hutan yang kelangsungan hidupnya bergantung pada hutan (seperti orang Dayak atau petani transmigran di Kalimantan; atau orang kecil/kerdil Bakolo atau petani Bantu di Kamerun) dengan pengguna hutan yang menggunakan hutan untuk meningkatkan pendapatan yang sudah cukup (seperti para raja kayu atau pegawai kehutanan).

\section{Pengetahuan Lokal}

Masyarakat yang telah tinggal di kawasan hutan sering memiliki pengetahuan unik dan berguna karena pengalaman lokal jangka panjang mereka. Pengetahuan ini dapat mengenai binatang dan perilakunya, tumbuhan dan 
pengelolaannya dan penggunaan bermacam hasilnya, teknik pemrosesan hasil hutan, dll. Pengetahuan lokal memiliki nilai sendiri, mengingat keterbatasan pengetahuan kami tentang ekologi hutan (terutama hutan tropis). Pengetahuan ini juga berfungsi penting dalam melibatkan penduduk lokal secara aktif dan secara menguntungkan dalam pengelolaan hutan. Pengakuan dari luar dan penggunaan pengetahuan mereka dapat dijadikan sebagai alat pemberdayaan penduduk lokal dan memperbaiki komunikasi dan kerjasama di antara mereka dan pengelola hutan lainnya.

\section{Integrasi Hutan/Budaya}

Budaya atau cara hidup - termasuk budaya masyarakat hutan - cenderung erat sekali hubungannya dengan lingkungan mereka. Mungkin ada tempattempat keramat di dalam hutan, sistem simbol yang memberi arti bagi kehidupan mereka dan sangat erat dengan perasaan masyarakat tentang diri mereka, adanya fungsi keamanan dari tumbuhan hutan selama musim paceklik, dan banyak sekali hubungan lainnya. Sejauh cara hidup penduduk terintegrasi dengan hutan, kelangsungan budaya mereka terancam oleh kehilangan hutan dan daftar keragaman budaya manusia menjadi semakin menurun. Terpecah belahnya disintegrasi budaya umumnya berpengaruh negatif tehadap kesejahteraan masyarakat.

\section{Defisit Kekuasaan}

Dalam banyak kawasan, kekuasaan penduduk yang tinggal di dalam atau di dekat hutan lebih lemah dibandingkan dengan stakeholder lain. Kekuasaan mungkin tergantung pada pendidikan, kekayaan, hubungan dengan pemerintah, atau lembaga lokal yang diakui. Di mana terdapat kekurangan kekuasaan lokal, pengaruhnya mungkin merugikan bagi hutan, karena 
penduduk tidak mempunyai cara-cara untuk melindungi sumber daya mereka dari tekanan luar. Akibatnya mungkin berupa degradasi lingkungan dan juga penurunan kesejahteraan manusia. Elemen lain yang terkait dengan isu kekuasaan adalah tentang pengetahuan siapa yang berkepentingan. Pembungkaman suara sebagian masyarakat yang berpotensi menimbulkan pengaruh berbahaya, seperti menurunnya kemampuan dan kemauan mereka untuk ikut serta dalam kerjasama pengelolaan hutan atau mengurangi akses pengelola formal terhadap pengetahuan yang berguna.

\section{ANALISIS KELOMPOK SASARAN}

\section{TUJUAN}

- Menyediakan konfirmasi sistematis tentang stakeholder lokal dan kelompok pengguna;

- Menilai persepsi lokal tentang distribusi kekuasaan di antara kelompokkelompok; ${ }^{8}$ dan

- Memperoleh tinjauan kualitatif tentang penggunaan hutan dan berbagai kecenderungan dalam kawasan hutan.

\section{BAHAN}

Menyesuaikan formulir yang tersedia di bawah dengan konteks lokal Anda; dan menyiapkan jumlah formulir yang cukup untuk setiap pertemuan yang Anda rencanakan. 'Flipchart' dan kertas yang lebar akan sangat membantu.

8 Informasi tambahan tentang kekuasaan mungkin penting untuk mengkonfirmasi kesimpulan dalam 'Matriks Siapa yang Berkepentingan'. Evaluasi terhadap perbedaan kekuasaan memang sulit. 
Beberapa peneliti menggunakan alat perekam (tetapi waktu untuk menulis hasil rekaman lebih lama).

\section{PESERTA}

Identifikasi stakeholder adalah bagian dari proses penilaian iteratif. Mengisi Matriks Siapa yang Berkepentingan mungkin langkah pertama. Melalui pembicaraan secara informal dengan pegawai lokal dan anggota masyarakat, Anda dapat mengembangkan pengertian tentang berbagai stakeholder. Bagi satu kelompok masyarakat, rencanakan untuk mengumpulkan paling sedikit tiga kelompok masing-masing terdiri dari 10 orang. Masing-masing kelompok dapat berupa kelompok pria/wanita, tua/ dewasa/muda, petani/peternak/ pemburu-pengumpul, pekerja perusahaan kayu/anggota masyarakat lokal/ pegawai kehutanan, atau lainnya, tergantung pada perbedaan-perbedaan yang secara lokal dianggap penting di antara masyarakat dan perbedaan polapola interaksinya. Perlu diingat bahwa dalam banyak kelompok, wanita tidak bersedia berbicara di depan para pria, sehingga yang diperlukan kelompok terpisah. Masukan dari para wanita diperlukan dan memerlukan perhatian khusus. Untuk ide-ide lainnya dalam hal menampung variasi masyarakat, lihat matriks Wollenberg dalam Panduan Pendamping Penilaian Dasar (PPPD). Kemungkinan, tidak mungkin membahas semua perbedaan sosial yang penting dalam satu metode ini saja. ${ }^{9}$

9 Tchikangwa dkk. (1998) memilih masyarakat lokal dan karyawan proyek konservasi. Mereka kemudian dapat memperoleh pandangan yang jelas tentang persepsi yang berbeda dari kelompok ini (bandingkan kriteria 2.3, 'Ada kesepakatan tentang hak dan tanggung jawab stakeholder yang relevan)'. 


\section{METODE $^{10}$}

Kelompok sasaran diatur menurut rangkaian pertanyaan dan/atau isu-isu. Pertanyaan dan isu-isu ini secara langsung dimasukkan dalam kerangka kerja yang tersedia dalam dua formulir yang dilampirkan (diidentifikasi dalam kurung sesudah masing-masing pertanyaan/isu). Walaupun kurang dikembangkan, versi formulir yang disajikan di sini sangat membantu ketika digunakan di Mt. Cameroon (Brocklesby dkk. 1997), para peneliti lain telah menyederhanakannya, dan hasilnya mungkin lebih sesuai untuk lokasi Anda. ${ }^{11}$

Kami menyarankan isu-isu/pertanyaan-pertanyaan berikut, tetapi sekali lagi kondisi lokal bisa saja beragam dan Anda mungkin perlu menyesuaikannya:

- Daftarkan kelompok-kelompok yang paling terlibat dalam penggunaan dan pengelolaan hutan serta urutkan mereka mulai dari yang terpenting ke yang kurang penting. [Dampak, formulir kekuasaan]

- Mengapa penduduk ini dinilai penting? [Formulir dampak]

- Apa kegiatan penting (merugikan/menguntungkan bagi lingkungan?) yang dilakukan kelompok pengguna ini? ${ }^{12}$ [Formulir dampak]

${ }^{10}$ Kami mengacu pada IUCN 1997:132-3 dan Brocklesby dkk. (1997). Metode ini telah diuji tambahkan oleh Diaw dkk. 1998, McDougall 1998; Porro dan Porro 1998; Sardjono dkk. 1997; Tchikangwa dkk. 1998; dan Tiani dkk. 1997.

${ }^{11}$ McDougall (1998), misalnya, menemukan bahwa pembedaan antara kepentingan dan kekuasaan sulit dilakukan di lapangan. Hal serupa juga dialami untuk membedakan kegiatan dan kepentingan.

12 Perundang-undangan perburuan, definisi batas-batas, mekanisme pemantauan merupakan contoh-contoh kegiatan yang berdampak positif, penebangan pohon untuk mengumpulkan buah, menangkap ikan dengan listrik, pemanenan berlebihan adalah contoh-contoh kegiatan yang berdampak negatif. 
- Apa kemungkinan dampak yang timbul jika kelompok-kelompok ini dilibatkan atau tidak dilibatkan dalam pengelolaan hutan secara formal? [Formulir dampak]

- Sebutkan kepentingan mereka dan urutkan, tunjukkan arah perubahan di masa depan. [Formulir kepentingan/kekuasaan]

- Urutkan kekuasaan mereka dan indikasikan arah perubahan di masa depan. [Formulir kepentingan/kekuasaan]

Pada waktu kelompok bertemu, jelaskan pada mereka maksud pertemuan. Isu-isu tersebut sangat sensitif dan harus ditangani secara hati-hati.

Jika mungkin satu orang harus menjadi moderator dan yang lain membuat catatan. Jika hal ini tidak mungkin, gunakan perekam sebagai alternatif, tetapi Tchikangwa dkk. (1998) menemukan bahwa pencatatan kembali hasil rekaman yang memakan waktu merupakan kelemahan dari cara ini. McDougall (1998) dan Porro dan Porro (1998) merekomendasikan penggunaan lembaran kertas (flipchart), karena merasa bahwa cara ini membuat penduduk merasa memiliki dan terlibat dalam hasil yang diperoleh. Mungkin akan lebih mudah untuk menggunakan gambar dalam flipchart daripada menggunakan kata-kata, terutama bila kebanyakan penduduk di dalam kelompok adalah buta huruf. Diaw dkk. (1998) menemukan bahwa proses ini menjadi sangat berguna dalam memberdayakan penduduk lokal.

Ketrampilan sebagai fasilitator yang baik adalah penting dalam menyelenggarakan pertemuan. Kemampuan untuk mengendalikan peserta yang terlalu cerewet dan memberi dorongan kepada orang-orang yang pendiam adalah sangat penting dan menentukan keberhasilan atau kegagalan suatu kelompok sasaran. Satu sesi sebaiknya berlangsung hanya sekitar satu jam, secara pasti tidak lebih dari dua jam, dan harus dalam suasana menyenangkan bagi peserta. 


\section{ANALISIS DAN KEGUNAAN SELANJUTNYA}

Dengan hati-hati ulas kembali catatan Anda setelah pertemuan, Anda mengisi formulir (untuk dampak dan kekuasaan), menyesuaikannya dengan konteks Anda. Setelah mengisi formulir, berdasarkan hasil diskusi Anda, periksa dengan beberapa peserta untuk memastikan pengertian Anda tentang maksud mereka. Tchikangwa dkk. (1998) merekomendasikan untuk mengisi formulir selama sesi kelompok berlangsung, jika waktu terbatas.

Proses ini akan memberikan pengertian kepada Anda tentang para pelaku utama dalam lingkungan lokal, dan beberapa petunjuk tentang kecenderungan dalam kawasan ini.

\section{Kekuatan (+) dan Kelemahan (-) Analisis Kelompok Sasaran}

$+\quad$ Peserta (terutama kelompok yang rentan) mungkin merasa lebih bebas berbicara ketika mereka berada dalam kelompok masyarakat yang mirip.

$+\quad$ Interaksi kelompok memperkaya kualitas dan kuantitas informasi yang mereka berikan.

+ Berbagai pendapat yang berbeda di antara kelompok-kelompok yang berbeda di dalam masyarakat dapat diidentifikasi.
Fasilitator mampu merangsang interaksi kelompok selama wawancara berlangsung.

Peralatan ini memerlukan beberapa interpretasi atas respon peserta oleh orang yang melengkapi analisis.

Masyarakat mungkin enggan berbagi pendapatnya dengan orang luar dan beberapa respon mereka mungkin tidak seluruhnya akurat. Membangun kepercayaan fasilitator dan dalam kelompok pada awal proses sering diperlukan agar informasi yang dikumpulkan valid dan lengkap. 


\section{SAMPELFORMULIR}

\section{Formulir Analisis Kelompok Sasaran}

\section{[Dampak]}

\begin{tabular}{|c|c|c|c|c|c|}
\hline \multirow{2}{*}{$\begin{array}{c}\text { Stakeholder/ } \\
\text { Kelompok } \\
\text { Pengguna }\end{array}$} & $\begin{array}{c}\text { Mengapa } \\
\text { kelompok } \\
\text { ini penting? }\end{array}$ & $\begin{array}{c}\text { Peran dalam } \\
\text { Pengelolaan } \\
\text { Hutan }\end{array}$ & $\begin{array}{c}\text { Kegiatan } \\
\text { Positif }\end{array}$ & $\begin{array}{c}\text { Kegiatan } \\
\text { Negatif }\end{array}$ & Dampak \\
\hline & & & & & \\
\hline
\end{tabular}




\section{SAMPELFORMULIR}

\section{Formulir Analisis Kelompok Sasaran [Kepentingan/Kekuatan]}

\begin{tabular}{|c|c|c|c|c|c|c|c|}
\hline \multirow{2}{*}{$\begin{array}{l}\text { Stakeholder/ } \\
\text { Kelompok } \\
\text { Pengguna }\end{array}$} & \multicolumn{4}{|c|}{ Kepentingan } & \multicolumn{3}{|c|}{ Kekuatan } \\
\hline & Uraian & Urutan & $\begin{array}{l}\text { Peru- } \\
\text { bahan }\end{array}$ & Alasan & Urutan & $\begin{array}{l}\text { Peru- } \\
\text { bahan }\end{array}$ & Alasan \\
\hline Orang Pygmi & $\begin{array}{l}\text { Akses ke kawasan berburu } \\
\text { Akses ke tumbuhan obat }\end{array}$ & 5 & - & & 1 & - & \\
\hline Bantu & $\begin{array}{l}\text { Ladang kacang tanah } \\
\text { Akses ke kawasan berburu } \\
\text { Ladang yang sedang } \\
\text { diberakan (hutan sekunder) }\end{array}$ & $\begin{array}{l}4 \\
3 \\
7\end{array}$ & $\begin{array}{l}- \\
-\end{array}$ & & $\begin{array}{l}3 \\
2 \\
2\end{array}$ & $\begin{array}{l}- \\
-\end{array}$ & \\
\hline Perusahaan Kayu & $\begin{array}{l}\text { Pembalakan } \\
\text { Daging satwa liar }\end{array}$ & $\begin{array}{l}1 \\
1\end{array}$ & $\begin{array}{l}- \\
+\end{array}$ & & $\begin{array}{l}9 \\
7\end{array}$ & $\begin{array}{l}= \\
+\end{array}$ & \\
\hline Proyek Konservasi & Perlindungan gorila & 10 & $=$ & & 3 & $=$ & \\
\hline
\end{tabular}

Menurut Kepentingan:

Urutan: 10 berarti bahwa kegiatan/peran stakeholder di dalam hutan mendukung pengelolaan hutan lestari.

1 berarti bahwa kegiatan/peran stakeholder di dalam hutan tidak mendukung pengelolaan hutan lestari.

Perubahan: Suatu estimasi peluang dan arah perubahan peran stakeholder dalam pengelolaan hutan lestari di masa yang akan datang.

Tanda tambah (+) berarti kegiatan stakeholder akan meningkatkan dukungan terhadap pengelolaan hutan lestari.

Tanda negatif (-) berarti kegiatan stakeholder akan meningkatkan gangguan terhadap pengelolaan hutan lestari.

Tanda sama dengan (=) berarti kegiatan stakeholder tidak akan berubah. 


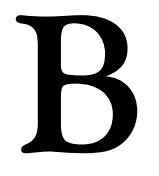

\section{Penilaian Keamanan Akses} Antargenerasi Terhadap Sumber Daya (40\%)

Pengalokasian 40\% untuk set kriteria dan indikator ini mencerminkan kesimpulan kami bahwa masalah keamanan akses antargenerasi terhadap sumber daya adalah suatu isu mendasar dalam pengelolaan hutan lestari. Penilaian ini merupakan cerminan dari tanggapan kami bahwa:

- ketersediaan sumber daya hutan secara lestari adalah sangat penting bagi masyarakat yang penghidupannya bergantung kepada sumber daya hutan;

- masyarakat yang mempunyai keamanan akses terhadap sumber daya hutan lokal, baik untuk mereka sendiri atau untuk keturunannya, cenderung lebih peduli akan hutannya; dan

- masyarakat yang merasa memperoleh manfaat-manfaat dari hutan secara adil cenderung memberikan efek positif terhadap hutan.

Angka persentase ini tidak harus tetap besarnya, namun, para penilai harus dapat mengadaptasinya sesuai dengan kebutuhan. Panduan pencatatan skor tersedia dalam Panduan Cara Pemberian Skor dan Analisis untuk Menilai Kesejahteraan Manusia.

Dalam kotak, Anda akan menemukan satu set Kriteria dan Indikator (K\&I) untuk keamanan akses antargenerasi terhadap sumber daya. 


\section{PRINSIP, KRITERIA DAN INDIKATOR YANG DIUSULKANUNTUK KEAMANANAKSES ANTARGENERASI TERHADAPSUMBER DAYA}

\begin{tabular}{|c|c|}
\hline P. 1 & $\begin{array}{l}\text { PENGELOLAAN HUTAN MENJAGA ATAU MENINGKATKAN AKSES } \\
\text { ANTARGENERASI TERHADAP SUMBER DAYA DAN BERBAGAI } \\
\text { MANFAAT EKONOMI SECARA ADIL (NILAI TOTAL }=40 \% \text { ) }\end{array}$ \\
\hline K. 1.1 & $\begin{array}{l}\text { Pihak pengelola lokal dapat secara efektif mengendalikan pemeliharaan dan } \\
\text { akses terhadap sumber daya }\end{array}$ \\
\hline I. 1.1 .1 & $\begin{array}{l}\text { Kepemilikan dan hak untuk menggunakan sumber daya (dalam satu generasi atau } \\
\text { antargenerasi) jelas dan mengakui klaim yang sudah ada }\end{array}$ \\
\hline I. 1.1 .2 & $\begin{array}{l}\text { Berbagai aturan dan norma dalam penggunaan sumber daya dipantau dan } \\
\text { ditegakkan pelaksanaannya }\end{array}$ \\
\hline I. 1.1 .3 & Cara-cara untuk mengatasi konflik berfungsi baik tanpa menggunakan kekerasan \\
\hline I. 1.1 .4 & Akses terhadap sumber daya dianggap adil oleh masyarakat lokal \\
\hline I. 1.1 .5 & Masyarakat lokal merasakan keamanan aksesnya terhadap sumber daya \\
\hline K. 1.2 & $\begin{array}{l}\text { Para pengelola hutan memperoleh manfaat ekonomi yang cukup dari hasil- } \\
\text { hasil hutan yang diambilnya }\end{array}$ \\
\hline I. 1.2 .1 & Mekanisme distribusi manfaat dianggap adil oleh masyarakat lokal \\
\hline I. 1.2 .2 & $\begin{array}{l}\text { Adanya kesempatan bagi masyarakat lokal dan masyarakat yang menggantungkan } \\
\text { hidupnya pada hutan untuk memperoleh pekerjaan dari perusahaan-perusahaan } \\
\text { kehutanan }\end{array}$ \\
\hline I. 1.2 .3 & Upah dan tunjangan lainnya sesuai dengan standar nasional dan/atau ILO \\
\hline
\end{tabular}


I. 1.2.5 Berbagai hasil hutan digunakan secara optimal dan adil

K. 1.3 Masyarakat mengaitkan masa depan mereka dan anak-anak mereka dengan pengelolaan sumber daya hutan

I. 1.3.1 Masyarakat menanamkan modal di lingkungannya (misalnya, waktu, tenaga, uang)

I. 1.3.2 Tingkat migrasi keluar rendah

I. 1.3.3 Masyarakat menyadari pentingnya keseimbangan antara jumlah penduduk dengan pemanfaatan sumber daya alam

I. 1.3.4 Anak-anak mendapatkan pendidikan (formal dan informal) tentang pengelolaan sumber daya alam

I. 1.3.5 Perusakan sumber daya alam oleh masyarakat lokal jarang terjadi

I. 1.3.6 Masyarakat memelihara hubungan batin dengan lahan hutan

Tiga metode berikut sangat membantu untuk menilai komponen keamanan akses antargenerasi terhadap sumber daya hutan: Maktriks Sejarah-Ekologi, Pemetaan Partisipatif, dan Akses Suatu Generasi terhadap Sumber Daya (Metode Distribusi Kerikil). ${ }^{13}$ Pembahasan masing-masing metode adalah sebagai berikut:

${ }^{13}$ Lihat juga metode distribusi kerikil pada Subseksi C (bawah). 


\section{MATRIKS SEJARAH-EKOLOGI \\ (Diadaptasi dari Mt. Cameron Project dan Anne Maria Tiani) ${ }^{14}$}

\section{TUJUAN}

- Untuk menilai perubahan-perubahan yang terjadi pada tingkat ketersediaan berbagai sumber daya setempat dengan berjalannya waktu, dengan proyeksi kecenderungannya di masa depan (Kriteria 1.1 dan 1.3); dan

- Untuk mengetahui penggunaan sumber daya, peraturan dan akses (Kriteria 1.1).

\section{PESERTA}

Pilih kelompok-kelompok yang terdiri dari 5-10 peserta berdasarkan kategorikategori pengguna hutan yang telah diidentifikasi sebelumnya. Dalam memutuskan berapa jumlah kelompok yang diperlukan, ingat bahwa kelompok-kelompok tersebut harus mencerminkan keragaman pandangan pria/wanita, orang tua atau pemuda, orang miskin dan kaya dan kelompok etnis setempat yang relevan. Bentuk kelompok baru bila diperlukan. Tempat yang berbeda mungkin menghasilkan perbedaan-perbedaan baru yang perlu untuk dimasukkan. Oleh karena itu jelilah untuk melihat kemungkinankemungkinan ini.

${ }^{14}$ Kilum Mountain Forest Project, Northwest Province, Kamerun juga menyajikan metode ini dalam suatu lokakarya pada bulan Nopember 1995. 


\section{BAHAN}

Anda perlu membuat suatu matriks. Idealnya, Anda memerlukan selembar kertas lebar yang di dalamnya telah tergambar suatu kotak-kotak yang cukup besar sehingga peserta dapat menempatkan kerikil (atau alat penghitung lain yang sesuai) dalam kotak-kotak tersebut. Untuk itu, Anda memerlukan 100 kerikil. $^{15}$

\section{METODE}

Kelompok ini terdiri dari tim penilai (seorang fasilitator dan seorang pencatat) dan wakil dari kelompok pengguna hutan tertentu. Cobalah untuk mengidentifikasi tanggal dari beberapa peristiwa lokal yang penting sebelum mengadakan pertemuan sehingga Anda bisa membantu untuk mengingatkan peserta yang kurang dapat mengingat tanggal-tanggal penting itu. ${ }^{16}$

- Jelaskan kepada masyarakat bahwa Anda tertarik untuk mengetahui bagaimana akses mereka terhadap sumber daya hutan yang mengalami perubahan dengan berjalannya waktu.

- Mintalah agar peserta dalam tiap kelompok mendaftarkan empat sumber daya hutan setempat yang penting bagi mereka. Kemungkinan besar hasil yang diperoleh berbeda menurut jenis kelamin, kelompok etnis, dll.

15 Benda kecil lain yang memiliki ukuran yang seragam juga dapat dipakai di sini. Diaw, misalnya, memakai biji kacang; Tim Sardjono, memakai kancing; McDougall, memakai biji jagung kering; Poro dan Porro, memakai biji coklat. Inilah kesempatan untuk mengembangkan kreativitas dan adaptasi yang sesuai dengan kondisi setempat.

${ }^{16}$ McDougall (1998) mengingatkan bahwa para penilai perlu mengetahui sejarah lokal dengan baik. Sebagian masyarakat di tempat ia melakukan penilaian berasal dari daerah lain, dan dalam beberapa kasus membawa nama desa bersama mereka. Data ini harus sudah diketahui agar hasil yang akurat bisa diperoleh. 
- Siapkan matriks dengan tanggal-tanggal sebelumnya (atau peristiwa penting setempat yang relevan) kira-kira dengan selang waktu lima tahun pada bagian atas matriks, sedangkan berbagai sumber daya yang penting didaftar pada sisi kiri kertas. Sediakan rentang waktu ke depan pada matriks ini (paling sedikit untuk 5 sampai 20 tahun). ${ }^{17}$

- Berikan 100 kerikil ini kepada kelompok dan mintalah mereka untuk menyebarkannya sepanjang tahun (gunakan 100 kerikil untuk setiap baris, atau setiap sumber daya), 100 kerikil tersebut mewakili sumber daya sepanjang waktu.

- Tanyakan mengapa mereka membuat alokasi kerikil seperti itu dan catat informasinya, dengan mengingat K\&I yang sedang Anda nilai. Catat juga alokasi kerikil yang mereka buat pada selembar kertas, untuk dijadikan rujukan pada tahap berikutnya.

Sementara peserta mendiskusikan isu-isu ini, cobalah untuk tetap mengingat dan menghubungkannya dengan K\&I, catatlah kejadian dan contoh-contoh kasus yang berkaitan dengan K\&I, untuk memasukkan data pada lembar isian K\&I induk. Sering informasi yang paling penting untuk penilaian Anda muncul dari jawaban/komentar tambahan atas sesuatu hal yang Anda tidak tahu bagaimana untuk menanyakannya. Hasil isian ini mencerminkan persepsi orang-orang terhadap kecenderungan perubahan ketersediaan

17 Günter (1998), dalam penelitiannya di Trinidad menemukan bahwa para respondennya tidak puas dengan pendekatan distribusi kerikil dan mengganti caranya dengan menggunakan kuesioner. Untuk mendata aspek-aspek keberlanjutan sumber daya, dia menanyakan 'Menurut Anda berapa (pada masa lalu, kini dan mendatang) luas hutan-hutan alam di Trinidad (dalam \% terhadap total luas lahan)? 1960—? Saat ini_—? dan pada tahun 2040_? ' Dia mengakhiri rangkaian pertanyaannya dengan menanyakan 'Apa dasar yang Anda gunakan untuk membuat estimasi: Pengurangan luas hutan atau pembatasan pengelolaan?' (kom. pri. 12/97). 
sumber daya. Oleh karena itu penting sekali bagi penilai untuk tetap merahasiakan pendapat mereka, agar pengaruh mereka terhadap hasil isian para responden dapat ditekan sekecil mungkin.

\section{WAKTU YANG DIPERLUKAN}

Rata-rata waktu yang dibutuhkan untuk setiap sesi pelatihan bagi dua orang fasilitator adalah dua jam. Waktu untuk mewawancarai setiap kelompok sekaligus untuk mengisi matriks dengan empat jenis sumber daya adalah setengah jam.

\section{ANALISIS DAN PEMBERIAN SKOR ${ }^{18}$}

Kegiatan ini membutuhkan proses tiga tahap. Pertama, Anda harus mengolah data dari penyebaran kerikil. Untuk itu data kerikil perlu dimasukkan ke dalam lembar isiannya sendiri. Dalam lembar isian ini Anda akan mencatat data penyebaran kerikil dari tiap kelompok. Data ini akan memberi petunjuk kepada Anda mengenai kecenderungan-kecenderungan yang berkaitan dengan sumber daya atau produk-produk yang dipilih.

Selanjutnya masukkan daftar K\&I (dalam kotak di atas) ke dalam sebuah lembar isian (bukan lembar isian induk Anda). Pertimbangkan informasi yang telah Anda catat selama berlangsungnya diskusi. Ketik secara ringkas kasuskasus dan kejadian yang terhimpun sesuai dengan kriteria atau indikator

18 Porro dan Porro (1998) menyarankan pembandingan hasil-hasil ini dengan hasil yang diperoleh dari metode distribusi kerikil pada 'akses suatu generasi terhadap sumber daya' (Panduan Pendamping Penilaian Dasar Kesejahteraan Manusia) untuk lebih memahami keamanan akses antargenerasi terhadap sumber daya secara lebih mendalam. Panduan lanjutan untuk analisis data ini dapat diperoleh pada bagian Panduan Cara Pemberian Skor dan Analisis untuk Menilai Kesejahteraan Manusia. 
yang tepat. Misalnya, jika Anda mendapatkan informasi tentang peraturan setempat, daftarkan keterangan ini pada Indikator 1.1.2. Jika orang-orang menyinggung kegiatan pembangunan gereja-gereja atau masjid-masjid, misalnya, ini merupakan contoh dari Indikator 1.3.1 (masyarakat menanamkan modal untuk lingkungan mereka). Ingatlah untuk mencatat setiap sumber (siapa, di mana) informasi yang Anda terima.

Terakhir, tetapkan skor untuk setiap kasus atau bukti, dengan cara memberi angka mulai dari 1 (yang paling tidak mendukung tercapainya kelestarian) sampai dengan angka 10 (sangat mendukung kelestarian). Masukkan skor dari tiap informasi ke dalam lembar isian induk menurut kriteria atau indikator yang sesuai.

\section{MATRIKS SAMPEL}

Matriks sampel ini mencerminkan versi awal metode yang tidak mencakup keadaan di masa depan. Anda perlu menyediakan paling sedikit dua kolom dengan rentang waktu lima dan 20 tahun kemudian. Porro and Porro (1998) menganggap bahwa secara praktis dapat digunakan paling banyak enam kolom untuk kurun waktu di masa depan ini. 
Tabel 1: Petani-petani wanita asli

\begin{tabular}{|l|r|r|r|r|r|r|r|r|r|r|r|}
\hline Sum ber daya & $\mathbf{1 9 6 2}$ & $\mathbf{1 9 6 7}$ & $\mathbf{1 9 7 2}$ & $\mathbf{1 9 7 7}$ & $\mathbf{1 9 8 2}$ & $\mathbf{1 9 8 7}$ & $\mathbf{1 9 9 2}$ & $\mathbf{1 9 9 7}$ & $\mathbf{2 0 0 2}$ & $\mathbf{2 0 1 7}$ & total \\
\hline Palem & 2 & 4 & 8 & 13 & 15 & 17 & 19 & 22 & & & 100 \\
\hline Sapi & 25 & 22 & 20 & 15 & 8 & 5 & 3 & 2 & & & 100 \\
\hline Egusi & 1 & 2 & 3 & 5 & 14 & 20 & 25 & 30 & & & 100 \\
\hline
\end{tabular}

(diadaptasi dari Brocklesby dkk. 1997)

\section{PEMETAAN PARTISIPATIF ${ }^{19}$}

\section{TUJUAN}

- Untuk mendapatkan persepsi masyarakat tentang hak-hak dan tanggung jawab yang berkaitan dengan sumber daya hutan lokal (Kriteria 1.1 dan 1.3); dan

- Untuk lebih memperjelas fungsi sistem pengelolaan sumber daya lokal (termasuk perangkat peraturan, pemantauan, sanksi, pemecahan konflik, dll) (Kriteria 1.1 dan 1.2)

\section{PESERTA}

Pilihlah kelompok-kelompok yang terdiri dari 5-10 peserta, lebih baik bila melibatkan para pengelola hutan yang berbeda (termasuk pemuda dan orang tua, kelompok etnis yang berbeda dan pekerjaan yang berbeda pula). Menurut pengalaman kami, pengelompokan menurut jenis kelamin lebih baik hasilnya. Latihan pemetaan seperti ini sering lebih informal dan lebih nyaman

19 Pembahasan lebih lanjut tentang pemetaan partisipatif, lihat Momberg dkk. 1996; Stockdale dan Ambrose 1996; Panday dkk. 1997; Joint Forest Management Support Project 1992 (I dan II); Molnar 1989; Bruce 1989, dll. 
dibandingkan penggunaan metode-metode lain, dan adanya interaksi berbagai sudut pandang yang berbeda pada metode ini akan menghasilkan isu-isu yang penting untuk dinilai. Evaluasi pengalaman Anda, dan lihatlah jika ada kategori peserta perorangan yang pendiam (tidak bersuara) (seperti kelompok etnis marginal, kasta yang lebih rendah). Mungkin latihan pemetaan dengan kelompok-kelompok ini perlu dilakukan secara terpisah. Pilihlah kelompokkelompok berbeda dan yang lebih heterogen daripada kelompok-kelompok yang dipilih dalam metode Matriks Sejarah-ekologi.

\section{BAHAN}

Peserta dapat menggambar peta pada selembar kertas berukuran besar, pada lembar-lembar transparansi (untuk membuat tampalan [overlay] isu-isu yang berbeda), atau secara sederhana digambar di atas tanah (yang kemudian dipindahkan ke atas kertas). Pakai alat tulis berwarna atau alat lain untuk menggambar. Porro dan Porro (1998) merekomendasikan penggunaan camcorder atau video recorder jika memungkinkan dan bila para peserta tidak keberatan.

\section{METODE}

Tim Anda akan membutuhkan seorang fasilitator dan seorang pencatat. Ingatkan para peserta untuk tetap mengingat $\mathrm{K} \& \mathrm{I}$ yang sedang Anda nilai. Salah satu keunggulan metode ini adalah kemampuannya untuk memunculkan isu-isu yang enggan dibicarakan oleh para peserta. Anda tidak perlu mempermasalahkan akurasi peta, tetapi yang lebih penting adalah melakukan identifikasi terhadap aspek-aspek sistem pengelolaan yang mereka terapkan dan pandangan mereka terhadap dunia mereka. Ajukan pertanyaan yang relevan dan yang berkaitan dengan keamanan kepemilikan mereka, 
berbagai isu pengelolaan (seperti pembagian akses, tenaga kerja dan kontrol), dan pembagian manfaat hutan, sambil Anda bekerja dengan masyarakat lokal untuk menggambar peta daerah mereka. Kadang lebih mudah memulai dengan suatu gambar atau peta yang disederhanakan untuk mengarahkan para peserta. Bersama kelompok, putuskan seberapa besar gambar daerah yang akan dibuat. Gambar ini harus cukup kecil agar dapat mencerminkan praktik-praktik pengelolaan sumber daya mereka sendiri dan praktik-praktik yang dilakukan oleh orang lain, yang berpengaruh penting dalam kehidupan mereka sehari-hari. Jika Anda mempunyai camcorder, Anda dapat memutar ulang apa yang telah Anda rekam dan memperoleh pengertian tambahan dari para peserta sambil mereka mengevaluasi apa yang telah mereka katakan.

\section{WAKTU YANG DIPERLUKAN}

Dua jam untuk persiapan fasilitator dan pencatat; dan sekitar dua jam untuk tiap kelompok.

\section{ANALISIS DAN PEMBERIAN SKOR}

Siapkan suatu lembar isian pemetaan, sekali lagi dengan daftar K\&I yang relevan. Catatlah kasus-kasus dan bukti-bukti yang muncul dalam latihan pemetaaan yang memberi kontribusi dalam penilaian Anda terhadap K\&I. Beri skor dari angka 1 (paling tidak mendukung kelestarian) sampai dengan angka 10 (paling mendukung kelestarian).

Ambil daftar induk K\&I dan berikan penilaian terhadap informasi yang telah Anda catat. Ringkaslah informasi baru yang telah Anda himpun dan yang berkaitan dengan K\&I ini. Misalnya, jika informasi mengenai konflik telah muncul, maka akan masuk dalam Indikator 1.1.3 dan/atau 1.2.1. Masukkan 
suatu versi singkat dari informasi ini beserta skornya pada lembar isian induk pada kriteria dan indikator yang sesuai, catat juga sumber informasinya.

\section{CONTOH PETA}

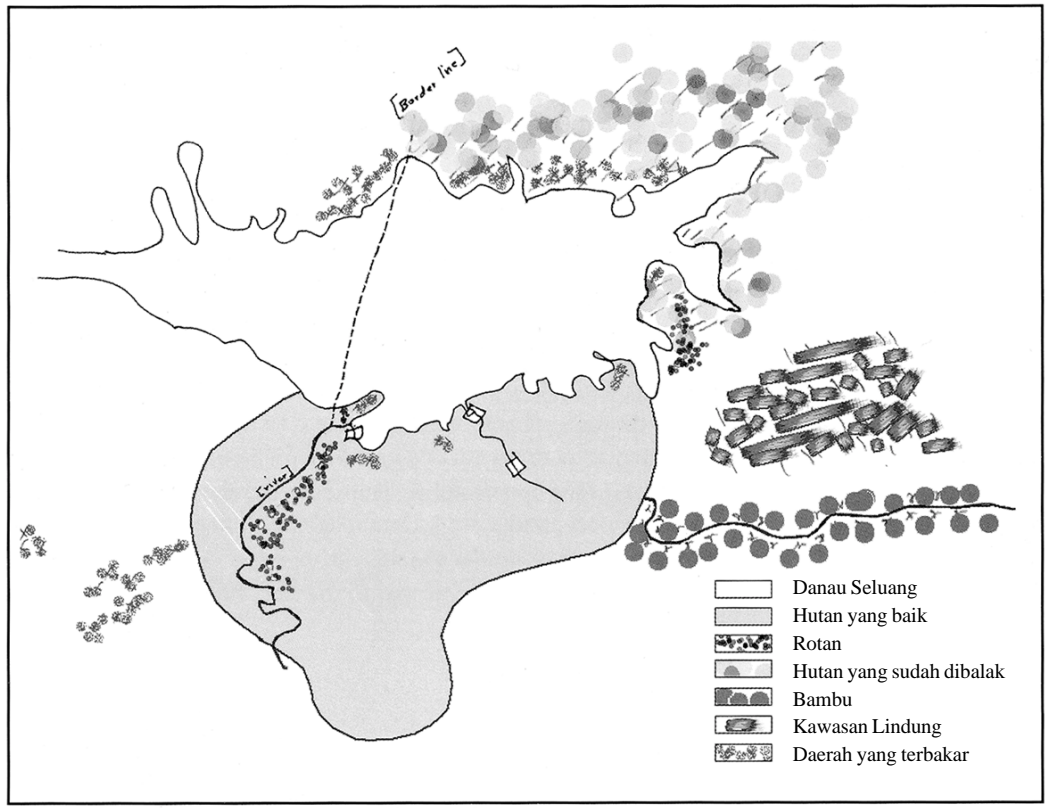

Peta wilayah desa di dekat Danau Seluang di bagian timur Suaka Margasatwa Danau Sentarum, Kalimantan Barat, Indonesia. 


\section{AKSES SUATU GENERASI TERHADAP SUMBER DAYA: METODE DISTRIBUSI KERIKIL ${ }^{20}$}

Menurut definisinya, pengelolaan hutan lestari mencakup elemen antargenerasi. Dalam metode ini, kami mencoba untuk menangkap jenisjenis perubahan yang terjadi dan juga persepsi masyarakat terhadap perubahan-perubahan itu.

\section{TUJUAN}

- Untuk menilai arah perubahan ketersediaan sumber daya di daerah itu (Kriteria 1.1); dan

- Untuk menilai perasaan-perasaan masyarakat menyangkut keamanan akses antargenerasi terhadap sumber daya (Kriteria 1.3; Indikator 1.1.5).

20 Karena tidak puas dengan pendekatan distribusi kerikil, Günter yang meneliti di Trinidad menggunakan kuesioner. Untuk mendapatkan data tentang aspek-aspek antargenerasi dalam kelestarian, dia mengajukan pertanyaan, '...silakan beri tanggapan tentang bagaimana akses terhadap sumber daya hutan berubah sepanjang waktu pada tiap generasi $(10=$ tinggi, $1=$ rendah): kakek—, diri sendiri_— pertanyaan 'Apa dasar estimasi yang Anda berikan: Berkurangnya luas hutan atau karena berbagai pembatasan dalam pengelolaannya?' (Kom. pri. 12/97). 


\section{PESERTA}

Pilih 12-15 peserta dari setiap kelompok stakeholder terpenting di daerah itu. ${ }^{21}$ Pastikan untuk menggunakan metode yang representatif: dengan memperhitungkan perbandingan jumlah antara pria dan wanita dan faktorfaktor keragaman sosial yang penting di daerah itu (umur, etnis, dll.). Penerapan metode distribusi kerikil secara individu atau secara kelompok homogen bergantung pada kondisi setempat dan juga pada pengalaman Anda dalam menerapkan metode-metode lain untuk keperluan ini. Dalam setiap kesempatan, jika Anda bekerja dengan suatu kelompok, pastikan untuk mencatat data demografis yang relevan (umur, jenis kelamin, etnis, pekerjaan dll.). Tingkat kepercayaan terhadap data dapat ditingkatkan bila responden kelompok umur yang sama dikumpulkan bersama, karena persepsi-persepsi tentang generasi berkaitan erat dengan umur para responden.

\section{BAHAN}

Lihat formulir di bawah. Siapkan 100 kerikil untuk disebarkan di antara tiga kategori: kakek, diri sendiri, cucu. ${ }^{22}$ Anda dapat menggunakan piring-piring atau Anda dapat membuat kotak-kotak kecil pada suatu kertas lebar untuk setiap generasi. Jika 100 kerikil dirasa terlalu banyak, pilih jumlah yang lebih kecil (50 atau 33 yang merupakan jumlah sederhana untuk menghitungnya). Anda perlu konsisten dengan jumlah ini.

21 Tujuan di sini bukan untuk menyediakan wakil-wakil secara proporsional dari para stakeholder, tetapi lebih untuk mendengar ragam pandangan dari setiap pengelola hutan di daerah itu.

22 Sardjono dkk. (1997) mengembangkannya menjadi lima kategori: kakek, orang tua, diri sendiri, anak-anak dan cucu. Porro dan Porro (1998) menggunakan kategori orang tua, diri sendiri, anak-anak dan cucu. 


\section{METODE}

Jelaskan mengapa Anda melakukan hal ini. Beritahu para peserta bahwa Anda tertarik untuk memahami bagaimana akses lokal terhadap sumber daya hutan berubah sepanjang waktu dan apa serta bagaimana tanggapannya terhadap ramalan-ramalan di masa datang. ${ }^{23}$ Mintalah kepada responden Anda (pria/wanita) untuk membayangkan keadaan sumber daya hutan secara keseluruhan sepanjang waktu (dari jaman kakeknya sampai masa kini bahkan sampai pada masa anak-cucunya). ${ }^{24}$ Minta responden untuk mengidentifikasi dirinya sebagai bagian dari suatu generasi (termasuk menyebutkan umur mereka) yang telah direkomendasikan. Pencantuman informasi ini akan membuat metode ini saling melengkapi dengan metode lain yang terkait dengan waktu. Metode ini kemungkinan besar akan menyediakan masukan berharga tentang perasaan orang-orang menyangkut keamanan dalam satu generasi, dan juga dapat melengkapi informasi yang dapat diperoleh dari Matriks Sejarah-ekologis. Porro and Porro (1998) menyarankan penggunaan metode berdasarkan generasi untuk melihat perubahan yang terjadi baik pada akses terhadap sumber daya maupun perubahan dalam kesejahteraan mereka. Satu syarat: Perjelas sejarah

23 Tchikangwa dkk. (1998) menemukan bahwa konsep 'akses terhadap sumber daya' sulit diterjemahkan ke dalam bahasa lokal. Untuk itu, mereka menggantinya dengan frekuensi konflik oleh generasi sebagai tolak ukur tingkat keamanan akses terhadap sumber daya. McDougall (1998) yang menemukan kendala yang sama, menjelaskan 'akses' secara lokal sebagai 'kelimpahan + kualitas dari sumber daya + kemampuan/ijin untuk menggunakannya.'

${ }^{24}$ Seseorang dapat menetapkan proporsi sumber daya yang diperoleh tiap generasi (sebagaimana dilakukan Tiani dkk. 1997) atau jumlah sumber daya yang tersedia untuk setiap generasi (seperti yang dilakukan Brocklesby dkk.1997). Salah satu dari kedua tafsiran ini dapat memberikan andil dalam pemahaman kita akan kriteria masing-masing. Namun jika studi banding antara beberapa tempat diinginkan, maka tafsiran yang sama harus dipilih. 
perpindahan masyarakat. Jika orang tua atau generasi kakek berasal dari suatu tempat yang jauh, maka implikasinya kelimpahan/kekurangan terhadap kondisi lokal harus ditafsirkan sesuai dengan informasi ini.

Penting sekali dijelaskan kepada anggota kelompok bahwa Anda tertarik untuk mengetahui tentang seluruh sumber daya hutan, sebelum mereka mengalokasikan kerikil-kerikil pada generasi tertentu. Mintalah agar peserta membagi 100 kerikil di antara beberapa generasi (kakek, diri sendiri, cucu). Para peserta bisa membuat penilaian kualitatif terhadap jumlah kerikil yang harus diletakkan pada setiap generasi (selanjutnya Anda harus menghitung jumlahnya). Catat alokasi itu pada formulir tersebut.

\section{WAKTU YANG DIPERLUKAN}

Inilah metode paling cepat yang telah kami coba. Dengan menyediakan waktu 1-2 menit per orang, jika dikerjakan secara perorangan, dan 15-30 menit untuk suatu kelompok yang terdiri dari 15 peserta (Tiany dkk. 1997). Sardjono dkk. (1997) melaporkan bahwa rata-rata waktu yang diperlukan adalah 4 menit setiap wawancara di suatu tempat dan di tempat lain 6 menit; Brocklesby dkk. (1997) menghabiskan rata-rata 7,8 menit untuk setiap wawancara. Mereka menghabiskan 4 jam untuk menyesuaikan pertanyaanpertanyaan itu dengan suatu daerah dan perlu waktu lebih dari 4,8 jam untuk melakukan wawancara (32 wawancara melibatkan 77 orang). Diaw dkk. (1998) menduga setiap wawancara memerlukan waktu 2 menit.

\section{ANALISIS DAN PEMBERIAN SKOR}

Data ini dapat dimasukkan ke dalam lembar isian suatu generasi (lihat Panduan Pemberian Skor dan Analisis untuk Menilai Kesejahteraan Manusia) 
dan lebih mudah untuk dianalisis. Analisis langsung yang paling diperlukan adalah untuk memutuskan bagaimana variasi distribusi kerikil menurut generasi secara rata-rata. Hasil dari analisis seperti ini akan lebih jelas jika Anda melakukan analisis yang sama menurut jenis kelamin peserta, kelompok etnis, pekerjaan dan terhadap berbagai kategori yang menurut penilaian Anda relevan di tempat penelitian Anda.

Kembali ke Kriteria 1.1, kita dapat menebak bahwa ketika jumlah kerikil yang ditempatkan seseorang dalam kotak anak cucunya secara nyata kurang dari kerikil generasinya sendiri atau generasi kakeknya, maka ada masalah tentang perasaan aman seseorang terhadap akses anak-anak mereka terhadap sumber daya hutan. Hasil yang sama juga dapat memberi petunjuk adanya masalah yang sesungguhnya dalam mempertahankan sumber daya. Hasil ini juga menunjukkan bahwa responden tidak mengaitkan masa depan anakanak mereka dengan pengelolaan sumber daya hutan (Kriteria 1.3). Perbedaan persepsi di antara stakeholder ini, mungkin bisa juga menjelaskan berbagai hal (dalam kaitannya tentang isu-isu keadilan - I.1.2.1, mekanisme pembagian manfaat, I.1.2.2, jenis pekerjaan; I.1.2.4, kerusakan).

Di Kamerun, Brocklesby dkk. (1997) dan Tiani dkk. (1997, lihat di bawah) menemukan antisipasi suatu kemerosotan yang nyata dalam hal sumber daya hutan di masa depan - yang menjelaskan adanya masalah kelestarian (mungkin bernilai 3, dalam sistem pemberian skor yang kita gunakan). Hasil penelitian Sardjono dkk. (1997) tampaknya menunjukkan pandangan yang lebih optimistik terhadap masa depan (dengan skor yang lebih tinggi) 


\section{FORMULIR SAMPEL DAN ANALISIS MENURUT SUATU GENERASI}

Akses terhadap sumber daya sepanjang waktu Metode Distribusi Kerikil

\begin{tabular}{|c|c|c|c|c|c|c|}
\hline \multirow{2}{*}{$\begin{array}{c}\text { Nomor } \\
\text { Responden }\end{array}$} & \multirow[b]{2}{*}{ Umur } & \multirow{2}{*}{$\begin{array}{l}\text { Kelompok } \\
\text { Suku }\end{array}$} & \multirow{2}{*}{$\begin{array}{c}\text { Jenis } \\
\text { kelamin }\end{array}$} & \multicolumn{3}{|c|}{ Generasi } \\
\hline & & & & $\begin{array}{c}\text { Kakek/ } \\
\text { nenek }\end{array}$ & $\begin{array}{c}\text { Diri } \\
\text { sendiri }\end{array}$ & cucu \\
\hline & & & & & & \\
\hline & & & & & & \\
\hline & & & & & & \\
\hline & & & & & & \\
\hline & & & & & & \\
\hline
\end{tabular}


Keempat kolom pertama disediakan untuk data demografis yang kemudian akan Anda pilah.

Tiga kolom terakhir disediakan untuk mendistribusikan ke 100 kerikil (atau menyatakan nilai persentase).

\section{CONTOH-CONTOH ANALISIS DATA}

Distribusi kerikil pada beberapa generasi, dengan memakai kategori jender dan kelompok (Mt. Cameroon) - Brocklesby dkk. 1997

\begin{tabular}{|l|l|c|c|c|c|c|}
\hline \multirow{2}{*}{$\begin{array}{c}\text { Jenis } \\
\text { Kelamin }\end{array}$} & Generasi & $\begin{array}{c}\text { Pegawai CDC } \\
(\mathrm{n}=17)\end{array}$ & $\begin{array}{c}\text { Petani asli } \\
(\mathrm{n}=20)\end{array}$ & $\begin{array}{c}\text { Orang asing } \\
(\mathrm{n}-20)\end{array}$ & $\begin{array}{c}\text { Pengguna } \\
\text { kayu (n-18) }\end{array}$ & $\begin{array}{c}\text { Jumlah } \\
\text { total }\end{array}$ \\
\cline { 3 - 7 } Wanita & Nenek & 43 & 72 & 65 & 56 & 62 \\
& Diri sendiri & 34 & 22 & 26 & 34 & 28 \\
& Cucu & 23 & 6 & 9 & 10 & 10 \\
\hline \multirow{2}{*}{ Pria } & Kakek & 53 & 54 & 57 & 54 & 54 \\
& Diri sendiri & 31 & 29 & 28 & 31 & 30 \\
\hline Total & Cucu & 16 & 17 & 14 & 15 & 16 \\
\hline Total & Kakek/Nenek & 50 & 62 & 61 & 55 & 57 \\
\hline Total & Diri sendiri & 32 & 26 & 27 & 32 & 29 \\
\hline
\end{tabular}




\section{Akses terhadap sumber daya sepanjang waktu}

(Diadaptasi dari Tiani dkk. 1997)

\begin{tabular}{|l|c|c|c|}
\hline \multicolumn{1}{|c|}{ Generasi } & Wanita & Pria & Rata-rata \\
\hline Kakek/Nenek & 24 & 25 & 25 \\
\hline Orang tua & 54 & 58 & 57 \\
\hline Cucu & 22 & 17 & 18 \\
\hline Total & 100 & 100 & 100 \\
\hline
\end{tabular}




\section{Penilaian terhadap Hak dan Kemampuan untuk Mengelola Hutan Secara Bersama dan Adil (30\%)}

Prinsip penilaian terhadap hak dan kemampuan untuk mengelola hutan secara bersama dan adil (lihat kotak), semula merupakan suatu syarat 'keterlibatan masyarakat lokal' dalam pengelolaan hutan. Setelah melakukan uji pendahuluan terhadap sejumlah metode yang difokuskan untuk mengukur partisipasi masyarakat, kami mengubah kata-katanya untuk mencerminkan fakta bahwa di sebagian besar kawasan hutan di dunia, masyarakat setempat telah melakukan fungsi-fungsi perngelolaan sehari-hari (lihat misalnya Colfer dkk. 1996a). Dalam beberapa kasus, isu yang dapat diterapkan adalah mensyaratkan partisipasi perusahaan-perusahaan kayu dalam pengelolaan hutan oleh masyarakat lokal. Oleh karena itu, kami menggunakan istilah 'hak dan kemampuan untuk mengelola hutan secara bersama dan adil'. ${ }^{25}$

Seperti pada bagian B, nilai persentase yang kami berikan (dalam hal ini 30) untuk bagian ini mencakup pengalaman-pengalaman kami sebelumnya dan cukup banyak berdasarkan pertimbangan. Menurut kami, isu tentang pengelolaan secara bersama adalah penting karena beberapa alasan berikut:

${ }^{25}$ Berbagai variasi prinsip ini telah dibahas, termasuk istilah 'hak dan kewajiban' (untuk menggantikan 'hak dan kemampuan'), 'untuk mengelola hutan secara bersama dan adil' (untuk menggantikan 'mengelola hutan secara bersama dengan adil'), 'Pengelola hutan' (untuk menggantikan 'Stakeholder yang berkepentingan'). Kami menyadari bahwa penggunaan istilah-istilah ini masih akan terus berubah. 
- Masyarakat setempat sering memiliki pengetahuan indijenus yang sangat berharga tentang berbagai manfaat dan kegunaan hutan, yang mungkin tidak dimiliki oleh stakeholder lain.

- Para pengelola hutan (masyarakat setempat dan para karyawan) berpotensi untuk memberikan pengaruh positif dan juga pengaruh negatif terhadap kelestarian hutan lokal, dan perhatian terhadap minat dan kepentingan mereka dapat memperbesar peluang terwujudnya pengaruhpengaruh yang positif.

- Ketergantungan, kemiskinan dan ketidakberdayaan para pengelola hutan mengharuskan adanya persyaratan etis agar kebutuhan-kebutuhan masyarakat ini dapat diatasi oleh kelompok-kelompok yang lebih makmur dan berkuasa, yang melakukan pemanenan sumber daya lokal.

Salah satu fungsi masyarakat untuk memiliki 'suara' dalam pengelolaan ditekankan oleh Tchikangwa beserta Tim penilai K\&I-nya pada 1996 (Prabhu dkk. 1998) - adalah untuk meyakinkan bahwa mereka berpengaruh atau memiliki kemampuan untuk melindungi dan mengelola sumber daya lokal (sebagaimana diuraikan sebelumnya pada bagian Keamanan Akses Antargenerasi terhadap Sumber Daya).

Seperti diuraikan sebelumnya, keyakinan kami tentang keuniversalan prinsipprinsip dan kriteria berikut lebih besar bila dibandingkan dengan keuniversalan indikator. 


\title{
PRINSIP, KRITERIA DAN INDIKATOR YANG DIUSULKAN UNTUK PENGELOLAANHUTANSECARA BERSAMA DAN ADIL
}

\author{
P. 2 STAKEHOLDER YANG RELEVAN MEMILIKI HAK DAN KEMAMPUAN \\ YANG DIAKUI UNTUK MENGELOLA HUTAN SECARA BERSAMA \\ DAN ADIL (NILAI TOTAL $=\mathbf{3 0} \%$ )
}

K. 2.1 Adanya berbagai mekanisme yang efektif untuk melakukan komunikasi dua arah antara para stakeholder dalam kaitannya dengan pengelolaan hutan

I. 2.1.1 > 50\% dari pegawai Departemen Kehutanan dan karyawan HPH dapat berbicara dalam satu atau beberapa bahasa lokal, atau > 50\% wanita lokal dapat menggunakan bahasa yang digunakan oleh HPH dalam berinteraksi

I. 2.1.2 Para stakeholder lokal bertemu dengan frekuensi yang cukup, keragaman lokal cukup terwakili, dan dengan kualitas interaksi yang cukup

I. 2.1.3 Kontribusi masing-masing stakeholder saling dihormati dan dihargai secara wajar.

K. 2.2 Para stakeholder memiliki pengetahuan yang lengkap tentang penggunaan sumber daya hutan (termasuk pengetahuan tentang kelompok-kelompok pengguna hutan dan peranan jender), dan juga pengetahuan tentang rencana pengelolaan hutan sebelum rencana tersebut dilaksanakan

I. 2.2.1 Adanya rencana/peta-peta yang menunjukkan pengintegrasian berbagai penggunaan hutan oleh berbagai stakeholder yang berbeda

I. 2.2.2 Rencana yang diperbarui, studi-studi dasar dan peta dapat diperoleh dengan mudah, yang menunjukkan rincian kawasan seperti penebangan hutan dan pembangunan jalan, disertai kerangka waktunya

I. 2.2.3 Studi-studi dasar tentang sistem masyarakat lokal juga tersedia dan diacu 
I. 2.2.4 Pegawai pengelola hutan mengakui adanya berbagai kepentingan dan hak stakeholder lainnya

I. 2.2.5 Pengelolaan hasil hutan nonkayu (HHNK) mencerminkan kepentingan dan hakhak stakeholder lokal

K. 2.3 Ada kesepakatan tentang hak-hak dan berbagai kewajiban stakeholder yang relevan

I. 2.3.1 Tingkat konflik yang ada dapat diterima oleh para stakeholder

Seperti diuraikan sebelumnya, Anda memerlukan sebuah lembar isian kerja untuk melakukan metode itu. Kemudian Anda perlu mengisi lembar isian K\&I induk di mana sekarang perhatian dipusatkan pada K\&I dalam kotak di atas. Seperti sebelumnya, Anda perlu menetapkan nilai estimasi sementara terhadap K\&I mulai dari 1 (tidak lestari) sampai dengan 10 (lestari).

Untuk memulai penilaian ini, pertama kali Anda harus mengunjungi kantor pusat perusahaan kayu setempat di kawasan ini. Indikator 2.1.1, misalnya, akan bermanfaat untuk menilai kemampuan pegawai perusahaan kayu untuk berbahasa daerah. Sebagian besar indikator pada Kriteria 2.2 akan dapat diperoleh di sana (misalnya, Indikator 2.2.1, tentang keberadaan dokumen perencanaan dan peta-peta, Indikator 2.2.3 tentang studi dasar terhadap sistem-sistem kemasyarakatan, Indikator 2.2.5 tentang pengelolaan HHNK). Demikian juga dengan Indikator 2.2.2, tentang ketersediaan dokumen-dokumen perencanaan, peta-peta dan penelitian-penelitian, yang perlu didapatkan dari desa-desa. Buatlah prakiraan awal dari setiap indikator ini, dan tulislah bukti dan dasar acuan estimasi Anda. 
Untuk melakukan penilaian terhadap masalah hak-hak bersama dan tanggung jawab bersama dalam mengelola hutan, kami menyarankan suatu metode yang lebih formal: Distribusi Kerikil 'Hak/kemampuan untuk mengelola hutan'. Penting sekali untuk mengingat bahwa sambil melakukan studi ini Anda akan terus berinteraksi dengan penduduk setempat, sehingga Anda berkesempatan untuk belajar lebih banyak secara kualitatif tentang keadaan masyarakat. Jangan mengabaikan informasi tambahan ini. Catat informasi ini dalam lembar isian K\&I yang telah Anda siapkan sebagai bukti atau kasus-kasus.

\section{HAK/KEMAMPUAN UNTUK MENGELOLA: DISTRIBUSI KERIKIL ${ }^{26}$}

\section{TUJUAN}

- Untuk mengetahui tingkat interaksi antara para stakeholder (merupakan prasyarat untuk menjalin kerjasama yang efektif dalam pengelolaan hutan Kriteria 2.1); dan

- Untuk mengidentifikasi bagaimana pembagian hak-hak pengelolaan dan kewajiban-kewajiban para stakeholder; serta kesepakatan-kesepakatan mereka tentang hak-hak dan kewajiban-kewajiban ini (Kriteria 2.2 dan 2.3).

${ }^{26}$ Dalam menciptakan metode ini, kami dipengaruhi karya Ostrom (1994) dan Gender Analysis and Forestry (1995). Pada mulanya metode yang kami kembangkan terpisah dari 'kemampuan' untuk mengelola, tetapi kami menyimpulkan bahwa fungsi-fungsi yang ada sudah memadai untuk mencerminkan aspek tanggung jawab pengelolaan; dan para peneliti merasa bahwa ada duplikasi yang cukup besar dalam tanggapan mereka terhadap 'hak dan kemampuan'. 


\section{PESERTA}

Anda memerlukan 12-15 jawaban dari setiap stakeholder, kelompok pengguna hutan atau kategori sosial lainnya yang akan Anda analisis. ${ }^{27}$ Dalam setiap ketegori ini paling tidak diperlukan keterlibatan pria dan wanita, kelompok etnis yang berbeda dan jenis pekerjaan yang berbeda. Di Kamerun, ketegori kelompok umur seperti orang tua, orang dewasa dan pemuda juga perlu dimasukkan. Anda perlu mendapatkan kelompok-kelompok yang memiliki hubungan yang jelas dengan pengelolaan hutan.

Anda dapat melakukan wawancara kelompok (5-15 orang) atau secara perorangan. Jika anda memutuskan untuk melakukan wawancara kelompok, pastikan agar kelompok itu bersifat homogen (misalnya, semuanya wanita, satu suku, memiliki jenis pekerjaan yang sama). Anda membutuhkan data kependudukan yang umum untuk tiap responden (umur, jenis kelamin, suku, dsb.) untuk membuat analisis selanjutnya, Anda perlu memahami bahwa kelompok yang berbeda memiliki kepentingan yang berbeda pula dan bias yang berbeda. Hal-hal di atas perlu diperhitungkan dalam menafsirkan jawaban mereka.

\section{BAHAN}

Mulailah dengan mengumpulkan 100 kerikil. Siapkan sebuah matriks dengan sejumlah kotak yang cukup besar sehingga memungkinkan orang-orang

27 Sekali lagi, tujuan metode ini bukan untuk mendapatkan keterwakilan yang proporsional, tetapi agar lebih memperbesar akses untuk mendapatkan pandangan yang beragam dari berbagai pengelola hutan lokal. 
menempatkan kerikil di sepanjang baris matriks itu ${ }^{28}$ Tiap baris berisi daftar fungsi-fungsi pengelolaan hutan (lihat di bawah). Tiap kolom memperlihatkan stakeholder terpenting (termasuk para pengelola hutan tetapi tidak terbatas). Brocklesby dkk. (1997) merekomendasikan pembuatan subkolom terpisah untuk tiap jender; sementara Porro and Porro (1998) tidak sependapat dengan cara tambahan ini. Mungkin lebih perlu membuat formulir terpisah yang terkait dengan peran pria dan wanita terhadap fungsifungsi pengelolaan, sebagai suatu cara untuk menyederhanakan proses wawancara. Buatlah lembaran-lembaran matriks yang lebih kecil untuk mencatat data yang Anda kumpulkan (Formulir A). ${ }^{29}$

Pada Formulir B, diperlukan kotak-kotak untuk setiap stakeholder yang dibuat menurun sepanjang sisi kiri halaman, dan sebelah kanan formulir disediakan untuk mencatat frekuensi interaksi di antara para stakeholder.

Sebelum memulai pertemuan dengan kelompok Anda, kajilah daftar K\&I di dalam kotak di atas, agar informasi yang Anda butuhkan tergambar jelas dalam pikiran Anda. Ide-ide dan tanggapan-tanggapan yang dikemukakan setiap peserta selama mendiskusikan topik-topik dalam formulir itu akan sangat bermanfaat sebagai hasil/data kuantitatif. Jangan lupa untuk mencatat

${ }^{28}$ Diaw dkk. (1998) memilih memakai piring-piring daripada menggunakan kolom-kolom untuk mewakili para stakeholder: dengan cara menempatkan 100 kerikil di antara piringpiring itu. Tiani dkk. (1997) menyarankan agar para responden memberi nilai bagi stakeholder: 20 poin seperti yang dilakukan sekolah-sekolah di Kamerun dan bukan 100 obyek fisik. Menurutnya, pemakaian 100 benda fisik terlalu besar, merepotkan dan memerlukan terlalu banyak perhitungan.

29 Porro dan Porro (1998) menyarankan untuk menggabungkan Formulir A dengan metode pemilihan kartu partisipasi (Panduan Pendamping Penilaian Dasar Kesejahteraan Manusia); dan memusatkan perhatian pada Formulir B. 
komposisi demografis kelompok Anda (suku, jenis kelamin, umur, pekerjaan, dll.) yang akan digunakan dalam menganalisis data.

\section{METODE}

Identifikasi tiga sampai lima kelompok stakeholder yang berperan penting dalam pengelolaan hutan, ${ }^{30}$ berdasarkan pada penilaian Anda sebelumnya (Bagian A). Kelompok-kelompok stakeholder ini akan dimasukkan dalam Formulir A dan B (lihat contoh di bawah), dan juga akan terwakili dalam responden sampel Anda (lihat di atas).

Jelaskan kepada para responden atau kelompok Anda bahwa Anda tertarik untuk mengetahui siapa yang mereka nilai bertanggung jawab untuk mengelola hutan di tempat mereka. Siapa yang sedang melakukannya sekarang? Jawaban pertanyaan ini harus dicatat dalam formulir. Pertanyaaan penting lain yang perlu diajukan untuk mengorek informasi adalah siapa yang menurut masyarakat setempat seharusnya berhak untuk mengelola hutan? Perjelas dalam benak Anda sendiri hutan apa yang paling sesuai dengan kebutuhankebutuhan Anda. Tegaskan apa yang Anda maksudkan dengan hak-hak.

Jelaskan tentang baris-baris yang mewakili hak-hak dan kewajiban-kewajiban yang berbeda dalam pengelolaan hutan dan tegaskan bahwa Anda ingin agar para peserta menempatkan ke 100 kerikil di antara daftar para stakeholder yang melintang di bagian atas matriks. Mereka perlu

30 Tiani dkk. (1997), sebagai contoh, menggunakan negara, jumlah penduduk lokal, industri kehutanan dan pekerja pengrajin, sebagai kelompok stakeholder yang dinilai. Brocklesby dkk. (1997) memakai penduduk asli, Proyek Konservasi Mt. Cameroon, pegawai-pegawai pemerintah, perusahaan kayu dan Cameroon Development Corporation. Sardjono dkk. (1997) memilih dua kelompok etnis, pemilik perusahaan kayu dan pemerintah. 
menempatkan 100 kerikil, satu kali untuk setiap baris. Mereka tidak harus menghitung jumlahnya; perkiraan secara kualitatif cukup memadai (namun Anda perlu menghitung jumlah kerikil-kerikil itu dan mencatat hasilnya pada kertas isian yang telah Anda siapkan).

\section{WAKTU YANG DIPERLUKAN}

Untuk menyesuaikan formulir isian Anda dengan kondisi lokal dan pelatihan para pegawai lapangan diperlukan waktu sekitar 4 jam. Kami berharap bahwa setiap wawancara membutuhkan waktu kurang dari satu jam. Waktu yang diperlukan untuk memasukkan data dan membuat analisisnya adalah 5 jam.

\section{ANALISIS DAN PEMBERIAN SKOR ${ }^{31}$}

Anda perlu menganalisis hasil-hasil wawancara menurut para stakeholder/ kelompok pengguna hutan, atau kategori sosial yang telah Anda pilih untuk diwawancarai. Berbagai fungsi pengelolaan hutan (kolom sebelah kiri) akan dirata-ratakan untuk setiap formulir dan untuk mewakili pengelolaan hutan secara keseluruhan. Hasil wawancara perorangan kemudian dipindahkan ke sebuah lembar isian 'hak-hak' di mana hasil dari seluruh formulir dalam kelompok tertentu itu akan dirata-ratakan (misalnya, semua responden wanita, semua responden Dayak, atau semua pengelola perusahaan kayu yang dijadikan responden). Dengan cara ini, skor rata-rata dari masingmasing stakeholder yang didaftar pada formulir (tiap kolom) dapat dibandingkan dengan hasil/skor kelompok. Pembandingan ini akan memberi informasi kepada kita apakah ada atau tidak ada kesepakatan tentang hak-

\footnotetext{
31 Panduan selanjutnya tentang analisis data ini ada dalam Panduan Cara Pemberian Skor dan Analisis untuk Menilai Kesejahteraan Manusia.
} 
hak dan tanggung jawab di antara para stakeholder (Kriteria 2.3), dan apakah para pengelola hutan yang formal mengakui atau tidak mengakui adanya kontribusi para pengelola hutan informal (Indikator 2.2.4).

Pertama-tama Anda akan mencari suatu pola kesepakatan umum di antara kelompok-kelompok responden (untuk Kriteria 2.3). Kemudian Anda akan memfokuskan diri pada respon para pengelola hutan formal untuk melihat apakah mereka mengetahui berbagai peran dari para pengelola lainnya (Indikator 2.2.4). Gunakan pola pemberian skor yang sama dengan yang Anda gunakan sebelumnya (lihat di bawah).

Kemudian Anda menganalisis Formulir B. Informasi apa yang telah Anda himpun dari berbagai interaksi masyarakat (Kriteria 2.1)? Apakah masyarakat lokal berinteraksi secara teratur dengan para pekerja perusahaan kayu? Adakah forum pertemuan di antara para stakeholder yang penting? Sekali lagi tetaplah memusatkan perhatian pada indikator-indikator dalam daftar pada kotak di atas, dan catat setiap fakta dan bukti yang Anda himpun dari wawancara-wawancara ini di lembar isian 'hak-hak' menurut kriteria dan indikator yang sesuai. Buatlah penilaian Anda mengenai tingkat kelestarian (nilai 1-10) untuk setiap bukti kecil yang muncul.

Langkah akhir merupakan langkah untuk melengkapi bagian ini pada lembar isian induk. Masukkan temuan-temuan Anda, baik secara kualitatif maupun kuantitatif, dengan skor yang sesuai, seperti yang telah Anda kerjakan pada metode-metode lainnya: nilai 1 untuk pola yang memperlihatkan tidak adanya kelestarian (tidak adanya kesepakatan tentang berbagai peran, tidak adanya penghargaan terhadap kontribusi lokal terhadap pengelolaan hutan) dan angka 10 untuk pola yang menunjukkan kelestarian tertinggi (adanya 
kesepakatan tentang berbagai peran dan adanya rasa hormat para pengelola formal terhadap masukan yang seimbang dari stakeholder yang lain). 


\section{SAMPEL FORMULIR ISIAN DAN SAMPEL ANALISIS}

\section{Formulir A - Hak/Kemampuan untuk Mengelola Hutan: Metode Distribusi Kerikil}

\begin{tabular}{|c|c|c|c|c|c|c|c|c|c|}
\hline \multirow{3}{*}{$\begin{array}{c}\text { Fungsi } \\
\text { Pengelolaan }\end{array}$} & \multicolumn{9}{|c|}{ Para Pengelola Hutan } \\
\hline & \multicolumn{2}{|c|}{ Orang Pygmi } & \multicolumn{2}{|c|}{ Bantus } & \multicolumn{2}{|c|}{ Negara } & \multicolumn{2}{|c|}{ Persh. Kayu } & \multirow[t]{2}{*}{ Total } \\
\hline & $\mathrm{P}$ & W & $\mathrm{P}$ & W & $\mathrm{P}$ & W & $\mathrm{P}$ & W & \\
\hline \multicolumn{10}{|c|}{$\begin{array}{l}\text { Menetapkan/ } \\
\text { Melindungi } \\
\text { tapal batas }\end{array}$} \\
\hline \multicolumn{10}{|c|}{$\begin{array}{l}\text { Mengembangkan/ } \\
\text { menetapkan peraturan/ } \\
\text { perundangan }\end{array}$} \\
\hline \multicolumn{10}{|c|}{$\begin{array}{l}\text { Melakukan } \\
\text { pemantauan } \\
\text { ketaatan/ } \\
\text { kepatuhan }\end{array}$} \\
\hline \multicolumn{10}{|c|}{$\begin{array}{l}\text { Memecahkan } \\
\text { berbagai konflik }\end{array}$} \\
\hline \multicolumn{10}{|c|}{$\begin{array}{l}\text { Menyediakan } \\
\text { kepemimpinan/ } \\
\text { organisasi }\end{array}$} \\
\hline \multicolumn{10}{|c|}{$\begin{array}{l}\text { Menilai denda/ } \\
\text { sanksi-sanksi }\end{array}$} \\
\hline \multirow[t]{2}{*}{ Jum lah } & $\mathrm{Jml}$. & $\mathrm{Jm} 1$. & $\mathrm{Jm} 1$. & $\mathrm{Jml}$. & $\mathrm{Jm} 1$. & $\mathrm{Jm} \mathrm{l}$. & $\mathrm{Jml}$. & $\mathrm{Jm} 1$. & \\
\hline & 600 & 600 & 600 & 600 & 600 & 600 & 600 & 600 & \\
\hline
\end{tabular}

Bagikan hak-hak dan tanggung jawab dalam mengelola hutan di antara para pengelola, bergantung pada jenis isu-isu pengelolaan yang terdapat pada sisi kiri matriks. Pembagian kerikil atau persentase nilai di antara para stakeholder (sepanjang baris), dibagi antara pria $(\mathrm{P})$ dan wanita (W). Akan sangat membantu bila Anda mengingat contoh-contoh setempat yang relevan. 
Pada contoh berikut, wanita dan pria dari Suaka Dja menempatkan kerikil di antara daftar stakeholder pada sisi kiri (Pemerintah, Kabupaten, dsb). Pengalokasian ini (diwakili oleh distribusi kerikil di antara stakeholder untuk setiap fungsi dari enam fungsi yang terdaftar pada formulir di atas) kemudian dirata-ratakan, untuk membuat penilaian secara keseluruhan terhadap 'hakhak untuk mengelola'. Jenis analisis ini dapat dikerjakan menurut kriteria jender (seperti di bawah), kelompok etnis, umur, atau ciri-ciri demografis lain yang sesuai.

\section{Perbedaan pendapat tentang Hak-hak untuk Mengelola Hutan menurut Jender (Suaka Dja)}

\begin{tabular}{|l|c|c|c|}
\hline \multicolumn{1}{|c|}{ Stakeholder } & $\begin{array}{c}\text { Wanita } \\
(\mathrm{N}=22)\end{array}$ & $\begin{array}{c}\text { Pria } \\
(\mathrm{N}=19)\end{array}$ & Rata-rata \\
\hline Pemerintah & 43 & 35 & 39 \\
Kabupaten & 12 & 16 & 14 \\
Lembaga pemb. & 5 & 4 & 5 \\
Perusahaan Kayu & 2 & 0 & 1 \\
Kelompok usia lanjut & 13 & 21 & 7 \\
Kako & 7 & 6 & 12 \\
Nzime & 13 & 11 & 6 \\
Baka & 6 & 6 & 7 \\
\hline
\end{tabular}

Baris yang dicetak miring menandakan bahwa ada ketidaksepakatan di antara pria dan wanita, menurut Uji Mann-Whitney dengan $\mu=0,05$. 


\section{SAMPEL FORMULIR ISIAN DAN SAMPEL ANALISIS}

\section{Formulir B - Tingkat Interaksi}

\begin{tabular}{|c|c|}
\hline Stakeholder & Alasan untuk berinteraksi \\
\hline $\begin{array}{l}\text { Suku Kenyah dan } \\
\text { Persh. HPH }\end{array}$ & $\begin{array}{l}\text { Perusahaan membangun ruas jalan melewati } \\
\text { perkebunan nenas penduduk; orang-orang Kenyah } \\
\text { meminta ganti rugi - telah dilakukan dua kali } \\
\text { pertemuan. }\end{array}$ \\
\hline $\begin{array}{l}\text { Persh. HPH dan } \\
\text { Suku Kenyah }\end{array}$ & $\begin{array}{l}\text { Pihak perusahaan ingin agar orang-orang Kenyah } \\
\text { menanam Acacia mangium untuk mendukung } \\
\text { perusahaan dalam melaksanakan program } \\
\text { penanaman - pihak perusahaan secara teratur } \\
\text { mengadakan kunjungan, sekali atau duakalidalam } \\
\text { seminggu. }\end{array}$ \\
\hline $\begin{array}{l}\text { Persh. HPH dan } \\
\text { Suku Kutai }\end{array}$ & $\begin{array}{l}\text { Pihak perusahaan tidak senang atas tindakan orang- } \\
\text { orang Kutai yang melakukan penebangan atas kayu- } \\
\text { kayu berharga - berkembang rumor bahwa pihak } \\
\text { perusahaan akan melaporkan hal itu ke pihak } \\
\text { kepolisian. }\end{array}$ \\
\hline $\begin{array}{l}\text { Suku Kutai dan } \\
\text { Persh. HPH }\end{array}$ & $\begin{array}{l}\text { Seorang gadis Kutai (beragama Islam) dihamili } \\
\text { pegawai perusahaan kayu beragama Kristen yang } \\
\text { berasal dari Indonesia bagian timur - merebaknya } \\
\text { pergunjingan yang mempertajam konflik, } \\
\text { merupakanisu yangsangatmudah untuk meletus. }\end{array}$ \\
\hline $\begin{array}{l}\text { Pemerintah dan } \\
\text { Persh. HPH }\end{array}$ & $\begin{array}{l}\text { Pihak pemerintah mencurigai telah terjadi } \\
\text { kecurangan dalam penyetoran bea penebangan } \\
\text { kayu; namun masalah ini sudah dipecahkan tanpa } \\
\text { adanya pengeluaran biaya tambahan resmi oleh } \\
\text { pihak perusahaan - diduga telah terjadi kolusi/kasus } \\
\text { suap ditingkatlokal. }\end{array}$ \\
\hline
\end{tabular}

Uraian kelompok: (mencakup jender, umur, suku dan penyebaran pekerjaan) Delapan orang petani wanita suku Kenyah, dengan rentang umur 18-45 tahun (Ini hanya sekedar contoh hipotetis) 


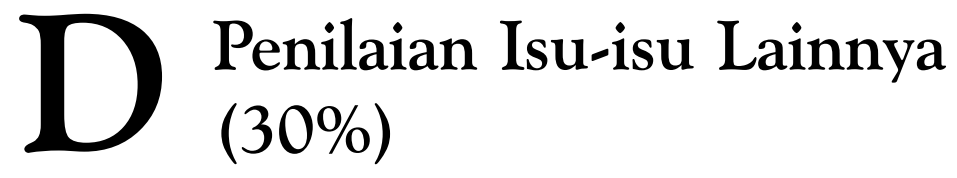

K\&I yang didaftar di bawah (lihat kotak) sampai sekarang belum menjadi fokus pengembangan dan pengujian metodologi oleh CIFOR. Namun, set K\&I ini mewakili sebagian sintesis dari hasil uji lapang sebelumnya untuk K\&I sosial yang belum diuraikan - yaitu setelah 'keamanan akses antargenerasi terhadap sumber daya' dan 'berbagai hak dan kemampuan untuk mengelola hutan secara bersama dan adil' telah diselesaikan. Karena menurut kami isu-isu lain ini adalah komponen penting dalam kesejahteraan masyarakat, kami telah memasukkannya seperti yang diuraikan berikut ini, dengan beberapa ide tentang bagaimana seseorang dapat menilainya. 


\title{
Prinsip, Kriteria dan Indikator yang Diusulkan untuk Kesehatan Pengelola Hutan, Kesehatan Budaya dan Kesehatan Hutan
}

\author{
P. 3 KESEHATAN HUTAN, PARA PENGELOLA HUTAN DAN BUDAYANYA \\ DAPAT DITERIMA OLEH SEMUA STAKEHOLDER (NILAI TOTAL = \\ $30 \%$ )
}

\section{K. 3.1 Ada keseimbangan yang cukup baik antara berbagai kegiatan manusia dan kondisi lingkungannya}

I. 3.1.1 Berbagai kondisi lingkungan yang dipengaruhi oleh kegiatan manusia tetap dalam keadaan stabil atau membaik

I. 3.1.2 Migrasi masuk dan/atau pertambahan penduduk secara alami selaras dengan pemeliharaan hutan

\section{K. 3.2 Ada pengakuan terhadap hubungan antara kesehatan masyarakat dengan pengelolaan hutan}

I. 3.2.1 Pihak pengelola hutan bekerjasama dengan pegawai kesehatan masyarakat dalam mengatasi berbagai penyakit yang berkaitan dengan pengelolaan hutan

I. 3.2.2 Status gizi masyarakat lokal cukup baik (misalnya, tingkat pertumbuhan tinggi dan berat badan anak-anak sesuai dengan standar internasional, tingkat kematian bayi dan balita rendah) $)^{32}$

I. 3.2.3 Para pegawai yang bekerja di bidang kehutanan memperhatikan persyaratanpersyaratan dan keamanan kerja sesuai dengan standar ILO dan bertanggung jawab atas risiko kesehatan yang berkaitan dengan pekerjaan mereka

32 Fakta bahwa indikator ini tidak selalu harus berhubungan langsung dengan kriterianya merupakan salah satu contoh kelemahan kriteria ketiga ini, yang disebabkan oleh kurangnya pengujian di lapangan yang dilakukan secara sistematis - dibandingkan dengan kedua kriteria lainnya. 


\section{K. 3.3 Ada pengakuan terhadap pentingnya keterkaitan antara pemeliharaan hutan dengan kebudayaan}

I. 3.3.1 Para pengelola hutan dapat menjelaskan keterkaitan antara budaya masyarakat dengan hutan lokal

I. 3.3.2 Rencana-rencana pengelolaan hutan mencerminkan perhatian terhadap isu-isu yang terkait dengan kebudayaan

I. 3.3.3 Tidak ada tanda-tanda tentang adanya perpecahan budaya

Kembali pada lembar isian pokok K\&I. Seperti Prinsip, K\&I lainnya, sementara Anda melakukan metode yang diuraikan dalam bagian terdahulu ingat juga K\&I ini. Jika Anda menyadari isu-isu ini, Anda akan menemukan bahwa Anda akan belajar lebih jauh tentang isu-isu ini dalam percakapan Anda dengan penduduk lokal, dengan karyawan perusahaan kayu dan dalam pengamatan sehari-hari Anda.

Untuk Kriteria 3.1, Anda perlu menggunakan lebih banyak penilaian pribadi. Misalnya, dampak peladangan berpindah (bentuk pertanian paling umum di kawasan tropis di mana perusahaan pembalakan beroperasi) terhadap lingkungan lokal bervariasi. ${ }^{33}$ Di banyak kawasan tempat kami telah bekerja, dampak peladangan berpindah tidak merugikan dengan masa bera yang lama dan berbagai sistem agroforestri. Di beberapa tempat lainnya, peladangan berpindah dapat merupakan cara penggunaan lahan yang merusak (terutama migrasi masuk oleh orang-orang yang tidak memiliki

${ }^{33}$ Untuk tinjauan umum yang baik tentang beberapa isu yang berkenaan dengan perladangan berpindah, lihat Warner (1991). 
tradisi pemanfaatan hutan - peladangan berpindah. Sebaiknya jangan terlalu percaya dengan apa yang Anda dengar. Temukan sendiri.

Untuk Indikator 3.1.1, periksa jangka waktu masa bera; lihat jika ada sistem tradisional yang rumit (dengan nama-nama yang berbeda untuk tahap-tahap dalam regenerasi hutan, dan berbagai kegiatan berbeda untuk mengumpulkan hasil dan mengelola tahap-tahap ini); tentukan ketergantungan masyarakat terhadap hutan (mungkin ada implikasi kondisi gizi yang penting sehubungan dengan kegiatan berburu, menangkap ikan dan mengumpulkan hasil hutan yang dianggap 'liar').

Untuk Indikator 3.1.2, pegawai kesehatan dan pegawai pemerintah lokal mungkin memiliki informasi yang relevan.

Untuk Kriteria 3.2, yaitu hubungan antara pengelolaan hutan dan kesehatan masyarakat, luangkan waktu bersama karyawan perusahaan kayu dan di tempat pembalakan.

Untuk Indikator 3.2.1, bicarakan dengan karyawan perusahaan kayu dan pegawai kesehatan lokal.

Untuk Indikator 3.2.3, amati kebiasaan sesungguhnya dari pekerja perusahaan kayu (apakah mereka memakai topi pengaman di kawasan bahaya atau tidak? Apakah mereka menggunakan sepatu pelindung selama menebang atau tidak?).

Untuk Indikator 3.2.2, luangkan waktu untuk berada di pusat kesehatan dan atau mengamati desa-desa lokal.

Untuk Kriteria 3.3, yaitu hubungan antara pemeliharaan hutan dan budaya, bicarakan dengan penduduk lokal dan dengan karyawan perusahaan kayu. 
Situasi paling umum yang kami temui adalah kekurangan pengetahuan dan rasa hormat karyawan perusahaan kayu dan pegawai kehutanan pemerintah terhadap budaya penduduk lokal. Tanpa pengetahuan dan rasa hormat tersebut, kerjasama pengelolaan sangat sulit, demikian juga usaha untuk memelihara sumber daya hutan dalam jangka waktu yang panjang.

Untuk Indikator 3.3.1, berkaitan dengan penilaian pengetahuan dan pemahaman pengelola formal, yang harus dilakukan di tempat karyawan perusahaan kayu bekerja (kamp kerja atau dalam kawasan penebangan hutan).

Untuk Indikator 3.3.2, berkaitan dengan dimasukkannya pengetahuan yang dimiliki ini ke dalam rencana pengelolaan yang akan membutuhkan penilaian tentang rencana-rencana dan implementasinya. Apakah integrasi ini benar terjadi di lapangan?

Indikator 3.3.3, tentang tingkat integritas budaya, perlu didiskusikan dengan penduduk lokal. Anda juga dapat menggunakan pusat kesehatan lokal dan informasi dari berbagai kantor pemerintah untuk membuat penilaian ini. Perubahan dalam jumlah kejahatan, penahanan, putus sekolah, migrasi ke luar, konflik antar suku adalah semua contoh indikator yang menunjukkan adanya masalah integritas budaya. 


\section{G Prosedur Pemberian Skor}

Anda sekarang telah memiliki lembar isian yang besar berisi ketiga prinsip, dan K\&I-nya. Di samping setiap indikator harus ada bukti atau kasus, masingmasing dengan skor kelestarian (1 untuk yang paling tidak lestari sampai 10 untuk yang paling lestari).

Identifikasilah K\&I yang tidak memiliki bukti atau skor untuk membuat penilaian. Lihat apakah Anda dapat mengisi beberapa kekosongan yang tersisa (dengan melakukan kunjungan khusus untuk membuat penilaian yang baru, atau dengan pengujian ingatan dan pemahaman Anda sendiri tentang seluruh situasi, atau dengan mendiskusikannya dengan anggota tim lain). Periksa bukti-bukti Anda secara kritis dan pastikan Anda hanya memasukkan bukti nyata dalam perhitungan Anda.

Untuk setiap indikator, hitung skor rata-rata yang Anda berikan untuk setiap bukti atau contoh kasus. Hitungan ini akan menghasilkan skor rata-rata untuk setiap indikator.

Sekarang hitung rata-rata skor yang Anda berikan untuk tiap indikator di bawah tiap kriteria. Hitungan ini akan menghasilkan rangkaian skor ratarata untuk setiap kriteria. Anda sekarang dapat menilai sejauh mana tiap kriteria dapat dipenuhi di dalam tiap prinsip.

Untuk menilai tiap prinsip, Anda kemudian dapat merata-ratakan skor untuk tiap kriteria dalam prinsip yang bersangkutan. Anda kemudian dapat mengatakan, misalnya, bahwa rata-rata seluruh skor kelestarian untuk keamanan akses antargenerasi terhadap sumber daya saat ini mungkin adalah 7 . 
Tahap akhir adalah membuat penilaian keseluruhan tentang kesejahteraan masyarakat. Kesejahteraan masyarakat ditentukan dengan menghitung ratarata kriteria di dalam setiap prinsip (lihat tahap sebelumnya), kemudian kalikan rata-rata ini dengan nilai persentase untuk prinsip tersebut (misalnya, jika skor rata-rata yang diberikan untuk kriteria keamanan akses antargenerasi terhadap sumber daya (prinsip 1) adalah 6, Anda mengalikan $6 \times$ 0,4). Hasil skor untuk tiga prinsip adalah jumlah skor ketiga prinsip, yang merupakan skor keseluruhan untuk kesejahteraan masyarakat. Skor keseluruhan 1-3 tidak dapat diterima. Skor 4-6 cukup. Skor 7-10 baik. Namun, jika ada kriteria individu dengan rata-rata di bawah 3, ini berarti bahaya dan para pengelola harus berusaha sungguh-sungguh memperbaiki pengelolaannya di bidang yang relevan ini - walaupun jika rata-rata seluruh skor berada di dalam kisaran yang dapat diterima.

Ingat bahwa kombinasi K\&I sosial ini (tiga prinsip) mewakili sepertiga dari penilaian hutan secara keseluruhan (dua per tiga lainnya berhubungan dengan ekologi dan pengelolaan hutan konvensional).

1. Pengelolaan hutan menjaga atau meningkatkan akses antargenerasi terhadap sumber daya dan berbagai manfaat ekonomi secara adil. (Nilai total $=40 \%$ )

2. Stakeholder yang relevan memiliki hak dan kemampuan yang diakui untuk mengelola hutan secara bersama dan adil. (Nilai total $=30 \%$ )

3. Kesehatan hutan, para pengelola hutan dan budayanya dapat diterima oleh semua stakeholder. (Nilai total $=30 \%$ ) 


\section{Glosari}

\section{Defisit kekuasaan}

Kekuasaan penduduk yang tinggal di dalam atau di dekat hutan sering lebih lemah dibandingkan dengan stakeholder lain. Di mana kekurangan kekuasaan lokal terjadi, pengaruhnya mungkin merugikan bagi mereka sendiri dan juga bagi hutan, karena penduduk tidak mempunyai cara-cara untuk melindungi sumber daya mereka.

\section{Hak-hak yang sudah ada}

Di banyak tempat yang hutannya dikelola secara komersial mungkin terdapat konflik paradigma tentang arti kepemilikan dan penggunaan lahan. Kadang masyarakat yang telah menempati kawasan tertentu selama beberapa dekade, abad bahkan milenium, akhir-akhir ini hak tradisional mereka telah direbut atau sangat ditekan. Baik secara keadilan maupun pragmatis hak masyarakat atas hutan perlu diakui dan dihormati.

\section{HHNK}

Hasil hutan nonkayu, juga sering disebut hasil hutan sampingan.

\section{Indikator}

Suatu indikator dapat berupa suatu variabel atau komponen ekosistem hutan atau sistem pengelolaan yang digunakan untuk menyimpulkan ciri-ciri kelestarian suatu sumber daya dan pemanfaatannya (Landres 1992; Prabhu dkk. 1996).

\section{Integrasi hutan/budaya}

Budaya atau cara hidup - termasuk budaya masyarakat hutan - cenderung erat sekali hubungannya dengan lingkungan mereka. Mungkin ada tempattempat keramat di dalam hutan, sistem simbol yang memberi arti bagi 
kehidupan mereka dan sangat erat dengan perasaan masyarakat tentang diri mereka, tumbuhan hutan merupakan fungsi pengamanan selama musim paceklik, dan banyak sekali hubungan lainnya.

\section{Kedekatan dengan hutan}

Masyarakat yang tinggal di dekat atau di dalam hutan memiliki lebih banyak peluang untuk mempengaruhi hutan dan dipengaruhi oleh hutan. Arti yang paling tepat tentang kedekatan dengan hutan ini tentu saja akan bervariasi menurut lokasinya, yang akan dipengaruhi oleh kualitas infrastruktur dan transportasi yang ada.

\section{Kelompok pengguna}

Pihak-pihak yang dapat diidentifikasi, memanfaatkan hutan dengan cara yang sama (misalnya, pemburu, pengumpul kulit kayu, peladang di hutan, pedagang hasil hutan nonkayu).

\section{Kemiskinan}

Penduduk yang standar hidupnya sangat rendah memerlukan perhatian khusus, karena keberadaan mereka merupakan suatu bukti adanya masalah 'kesejahteraan manusia'.

\section{Ketergantungan}

Sebagian dari stakeholder mengandalkan penghidupannya kepada hutan. Mereka mencari makan melalui berburu, menangkap ikan, mengumpulkan makanan, obat dan serat, atau melakukan agroforestri. Sumber daya alam yang merupakan basis sistem ekonomi mikro masyarakat ini memiliki berbagai implikasi yang penting terhadap kesejahteraan mereka, dan akhirnya akan berimplikasi terhadap hutan. 


\section{Kriteria}

Kriteria merupakan suatu titik tengah di mana informasi yang disediakan dari indikator dapat diintegrasikan dan cara penilaian yang dapat ditafsirkan menjadi semakin jelas (Prabhu dkk. 1996).

\section{Pengelola hutan}

Salah satu kategori stakeholder yang dipandang penting oleh perusahaan kayu dalam melakukan pengelolaan hutan; kelompok masyarakat yang dianggap penting dalam pengelolaan hutan lestari (Colfer 1999).

\section{Pengelolaan Hutan Lestari}

Cara-cara pengelolaan hutan dengan tetap mempertahankan atau bahkan meningkatkan berbagai fungsi ekologis hutan dan kesejahteraan manusia.

\section{Pengetahuan lokal}

Masyarakat yang telah tinggal di kawasan hutan sering memiliki pengetahuan unik dan berguna karena pengalaman lokal jangka panjang mereka. Pengetahuan ini dapat dimanfaatkan untuk meningkatkan kualitas pengelolaan hutan, dan juga sebagai alat pemberdayaan penduduk lokal untuk mengemukakan pendapat mereka tentang masa depan.

\section{Pengukur (verifier)}

Data atau informasi yang membuat suatu indikator menjadi lebih spesifik atau meningkatkan kemudahan untuk melalukan penilaian terhadap indikator (Prabhu dkk. 1996).

\section{Prinsip}

Adalah suatu kebenaran atau hukum yang digunakan sebagai landasan berpikir atau bertindak (Oxford Dictionary of Current English 1987, Prabhu dkk. 1996). 
Stakeholder

Perorangan atau kelompok yang memiliki kepentingan terhadap hutan. 


\section{Daftar Pustaka}

Brocklesby, M. A., P. Etuge, G. Ntube, J. Alabi, M. Anje, V. Bau Bau, dan J. Molua. 1997. CIFOR Cameroonian test of social methods for assessing criteria and indicators for sustainable forest management. Mt. Cameroon Project, Limbe, Cameroon. CIFOR Report, Bogor, Indonesia.

Bruce, J.W. 1989. Community forestry: rapid appraisal of tree and land tenure. FAO, Rome.

Colfer, C.J.P. 1995. Who counts most in sustainable forest management. CIFOR Working Paper No. 7. CIFOR, Bogor, Indonesia.

Colfer, C.J.P. 1997. A test of social science assessment methods. CIFOR methods testing manual. CIFOR, Bogor, Indonesia.

Colfer, C.J.P. dan R.L. Wadley. 1996. Assessing 'participation' in forest management: Workable methods and unworkable assumptions. CIFOR Working Paper No. 12. CIFOR, Bogor, Indonesia.

Colfer, C.J.P., dengan R. Prabhu dan E. Wollenberg. 1995. Principles, criteria and indicators: applying Ockham's Razor ti the people-forestry link. CIFOR Working Paper No. 8. CIFOR, Bogor, Indonesia.

Colfer, C.J.P., R.L. Wadley, J. Woelfel dan E. Harwell. 1997a. From heartwood to bark: Indonesian gender issues in sustainable forest management. Women in Natural Resources 18: 7-14.

Colfer, C.J.P., R.L. Wadley, E. Harwell dan R. Prabhu. 1997b. Intergenerational access to resources: developing criteria and indicators. CIFOR Working Paper No. 18. CIFOR, Bogor, Indonesia. 
Colfer, C.J.P., R.L. Wadley, J. Woelfel dan E. Harwell. 1996b. Assessing people's perceptions of forest in Danau Sentarum Wildlife Reserve. CIFOR Working Paper No. 13. CIFOR, Bogor, Indonesia.

Colfer, C.J.P., dengan R. Prabhu, M. Günter, C. McDougall, N. M. Porro, dan R. Porro. 1999. Who counts most? Assesing human well-being in sustainable forest management. Criteria \& Indicators Toolbox Series No. 8. CIFOR, Bogor, Indonesia.

Diaw, C., R. Oyono, F. Sangkwa, C. Bidja, S. Efoua dan J. Nguiebouri. 1998. Social science methods for assessing criteria and indicators of suatainable forest management: a report of the tests conducted in Cameroon humid forest benchmark and in the Lobe and Ntem River basins - Part 1. CIFOR Report. Bogor, Indonesia.

Federal Ministry for Environment, Youth and Family. 1996. Testing of criteria and indicators of sustainable forest management within the international CIFOR project. Federal Environment Agency, Vienna.

FAO. 1995. Gender Analysis and Forestry. Forest, tress and people programme, Rome.

Günter, M. 1998. Intergenerational equity and sharing of benefits on an island state. Prepared for inclusion in: Colfer (ed.) Local people in logged forests: Wellbeing under scrutiny. CIFOR, Bogor, Indonesia.

IUCN. 1997. Beyond fences: seeking social sustainability in conservation. Volume 2: a resource book. IUCN, Gland.

Joint Forest Management Support Project. 1992. Field methods manual I and II. Society for Promotion of Wastelands Development, New Delhi. 
Landres, P.B. 1992. Ecological indicators: Panacea or liability. Dalam: D.H. McKenzie, D.E. Hyatt dan J.E. McDonald (eds), Ecological Indicators, Volume 2, h. 1295-1318. Elsevier Applied Science, London.

McDougall, C. 1998. Final test of the social science methods, Bulungan, East Kalimantan. CIFOR Report. CIFOR, Bogor, Indonesia.

Molnar, A. 1989. Community forestry: rapid appraisal. Community Forestry Note 3. FAO, Rome.

Momberg, F, K. Ato dan M. Sirait. 1996. Drawing in local knowledge: a community mapping training manual: case studies from Indonesia. Ford Foundation, Yayasan Karya Sosial Pancur Kasih, and WWF, Jakarta, Indonesia.

Mount Cameroon Project. 1996. Stakeholder analysis for participatory resource management. Community Development Dept., Forest Management Dept., and MINAGRI staff, Limbe, Cameroon.

Ostrom, E. 1994. Neither market nor state: governance of common-pool resources in the twenty-first century. International Food Policy Research Institute, Washington, DC.

Oxford Dictionary of Current English. 1987. Oxford University Press, New York.

Pandey, D.N., S. Chadha, A. Chatterjee, A. Swarz, dan M. Poffenberger. 1997. Participatory mapping for joint forest management inventory, planning, and monitoring: methods manual (Volume Three). Asia Forest Network, Barkeley and New Delhi.

Porro, R. dan N.M. Porro. 1998. Methods for assessing social science criteria and indicators for the sustainable management of forests: Brazil test. CIFOR Report, Bogor, Indonesia. 
Prabhu, R., C.J.P. Colfer, P. Venkateswarlu, L.C. Tan, R. Soekmadi dan E. Wollenberg. 1996. Testing criteria and indicators for sustainable management of forest: Phase I final report. CIFOR Special Publication. CIFOR, Bogor, Indonesia.

Prabhu, R., W. Maynard, R. Eba'a Atyi, C.J.P. Colfer, G. Shepherd, P. Venkateswarlu dan F. Tiayon. 1998. Testing and developing criteria and indicators for sustainable forest management in Cameroon: the Kribi test - Final report. C\&I Toolbox. CIFOR, Bogor, Indonesia.

Prabhu, R., M. Haggith, H. Purnomo, A. Rizal, D. Sukadri, J. Taylor dan Y. Yasmi. 1999. CIMAT (Criteria and indicators modification and adaption tool). Criteria \& Indicators Toolbox Series No. 3. CIFOR, Bogor, Indonesia.

Sardjono, M.A., E. Rositah, A. Wijaya, dan E.M. Angie. 1997. A test of social science assessment methods concerning indicators and criteria for sustainable forest management in East Kalimantan. CIFOR Report. CIFOR, Bogor, Indonesia.

Stockdale, M. dan B. Ambrose. 1996. Mapping and NTFP inventory: Participatory assessment methods for forest-dwelling communities in East Kalimantan, Indonesia. Dalam: J. Carter (ed.), Recent approaches to participatory forest resource assessment, h. 170-211. Rural Development Forestry Study Guide 2. ODI, London.

Tchikangwa, B.N., dengan S. Sikoua, M. Metomo dan M.F. Adjudo. 1998. Test des méthodes en sciences sociales de vérification des critères et indicateurs d'aménagement durable des forêts: Périphérie est de la Réserve du Dja (SudCameroun). CIFOR Report. CFOR, Bogor, Indonesia.

Tiani, A. M., dengan E. Mvogo Balla, A. Oyono dan E. Kenmegne Diesse. 1997. A test of social science assessment methods (near Mbalmayo, Cameroon). Re- 
port to CIFOR, Assessing Sustainable Forest Management: Testing Criteria and Indicators Project, Mbalmayo. CIFOR Report. CIFOR, Bogor, Indonesia.

Warner, K. 1991. Shifting cultivators: local technical knowledge and natural resource management in the humid tropics. Community Forestry Note 8. FAO, Rome. 


\section{SistemCGIAR}

The Consultative Group on International Agricultural Research (CGIAR) adalah suatu asosiasi informal yang terdiri dari 41 organisasi donor dari sektor publik dan swasta yang mendukung jaringan enam belas lembaga penelitian internasional di bidang pertanian, di mana CIFOR merupakan anggota terbaru. Asosiasi ini didirikan pada tahun 1971. Pusat-pusat CGIAR merupakan bagian sistem penelitian global di bidang pertanian yang berusaha menerapkan kemampuan ilmiah internasional untuk menyelesaikan masalah-masalah yang dihadapi olehmasyarakatmiskin di dunia.

\section{CIFOR}

CIFOR adalah bagian sistem CGIAR dengan tugas khusus untuk menanggapi kepedulian global tentang dampak kerusakan dan kehilangan hutan terhadap kondisi sosial, lingkungan dan ekonomi masyarakat. CIFOR beroperasi melalui berbagai kemitraan yang sangat terdesentralisasi dengan lembaga-lembaga dan/atau individu terpenting di seluruh negara industri dan negara yang sedang berkembang. Sifat dan jangka waktu kemitraan ini ditentukan oleh masalahmasalah penelitian khusus yang dihadapi. Agenda penelitian ini terus-menerus dikaji dan selalu mengalami perubahan ketika para mitra menemukan berbagai masalah dan peluang baru. 
Panduan Penilaian Dasar Kesejahteraan Manusia (PPD) difokuskan pada kriteria dan indikator sosial untuk pengelolaan hutan lestari (PHL), suatu topik yang selama ini dianggap kontroversial dan dilingkupi ketidakpastian. Panduan ini dirancang untuk masyarakat yang berkepentingan dalam menilai pengelolaan hutan lestari, tetapi untuk yang tingkat keahliannya dalam bidang sosial tidak cukup tinggi. Enam metode sederhana yang dijelaskan dalam panduan ini dirancang untuk digunakan oleh ilmuwan biofisika dengan pendidikan perguruan tinggi. Perangkat ini juga dapat digunakan oleh para penilai yang keahliannya di bidang-bidang sosial lebih tinggi, tetapi disajikan dalam format 'buku resep'. Panduan Cara Pemberian Skor dan Analisis untuk Menilai Kesejahteraan Manusia, yang digunakan bersama Panduan Penilaian Dasar Kesejahteraan Manusia, menyajikan cara penilaian tambahan untuk mengetahui tingkat kesejahteraan manusia, termasuk metode khusus pemberian skor. Perangkat ini juga menyajikan panduan analisis untuk tingkat yang lebih rinci. 